\title{
الديّمقراطيّة الرّوحيّة: مراجعة لمقالة "الاجتهاد" عند محمّد إقبال
}

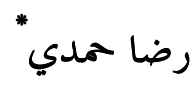

$$
\begin{aligned}
& \text { الملخص } \\
& \text { تبحث هذه الورقة في دعوة محمّد إقبال إلى إعادة الاعتبار لمبدأ الحركة في الفكر الإسلامي، بوصفه مبدأ قر آنيّاً }
\end{aligned}
$$

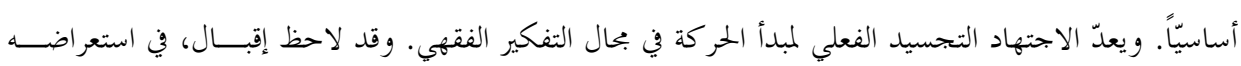

$$
\begin{aligned}
& \text { لصفحات من تاريخ مفهوم الاجتهاد، أنّه كان الأداة المثلى لتجديد الفكر التشريعي الإسلامي. ويقتضــي إحيــاء } \\
& \text { العمل بالاجتهاد اليوم إعادة النظر في مبادئ أصول الفقه وفروعه. وقد أدّاه النظر في فروع الأحكام الفقهيـــة إلى } \\
& \text { الكشف عن ممكنات التجديد فيها، خاصّة في الجانبين السياسي والاجتماعي، وذهب في مر اجعة الأصول إلى إبراز }
\end{aligned}
$$

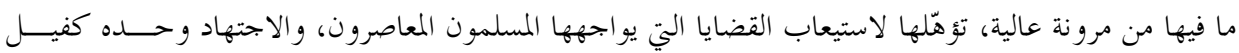

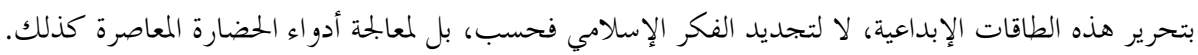

$$
\begin{aligned}
& \text { الكلمات المفتاحية: اجتهاد، حر كة، علم الأصول، علم الفقه، التجديد. }
\end{aligned}
$$

\section{Spiritual Democracy: A Review of "al-ijtihad" Article by Muhammad Iqbal}

\begin{abstract}
This paper examines Muhammad Iqbal call to re-consider the principle of dynamics in Islamic thought, as a fundamental principle of Qur'an. Ijtihad is the actual embodiment of dynamism in the field of jurisprudent thinking. In his review of the history of ijtihad concept, Iqbal demonstrates that it was the perfect tool for the renewal of Islamic legislative thought. Furthermore, ijtihad revival the present requires a review of the principles of jurisprudence and its branches. Iqbal's review into these principles lead him to detect their renewal possibilities, especially in political and social aspects. Accordingly, he highlights the flexibility of these principles to cope with modern issues that Muslims face, and proclaims that Ijtihad alone guarantees to release the creative potentials, not only to renew Islamic thought, but also to address modern civilization problems as well.
\end{abstract}

Keywords: Ijtihad (diligence), Dynamism, 'Ilm al-Usul (Science of the principles of Islamic Jurisprudence), Science of jurisprudence, Renewal.

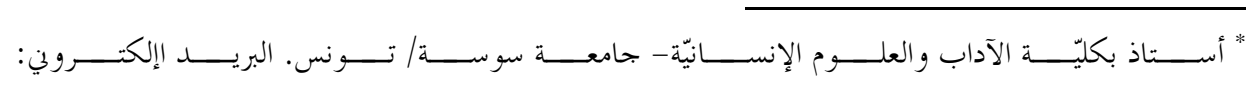

$$
\begin{aligned}
& \text { hamdiridha2007@yahoo.fr }
\end{aligned}
$$

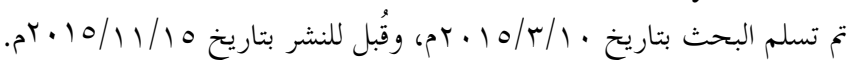




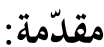

مثّلت الدّعوة إلى إعادة تفعيل مبدأ الاجتهاد، محوراً مر كزيّاً في تفكير محمّد إقبال،

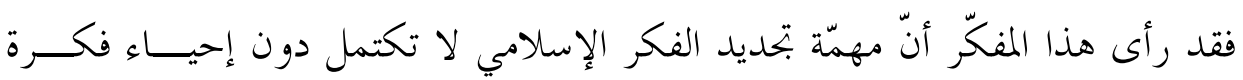

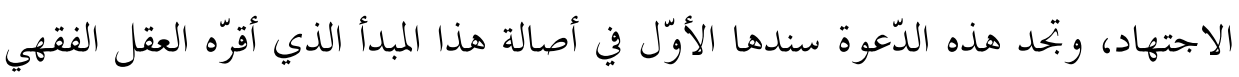

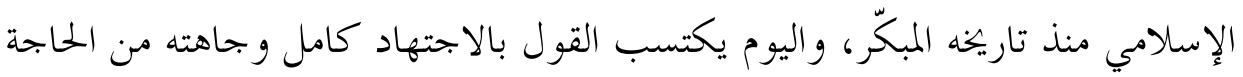

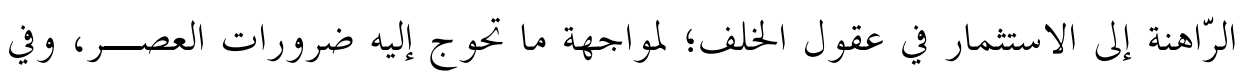

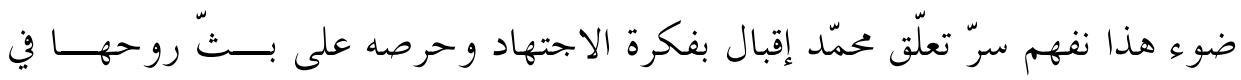

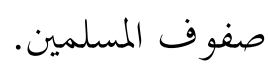

والتّعريف بمضامين الدّعوة إلى إعادة تفعيل الاجتهاد هو محاولة لاستيعاب الدّرس

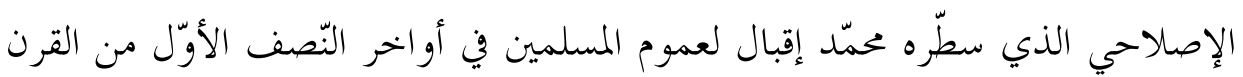

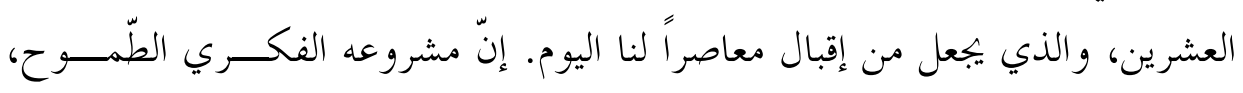

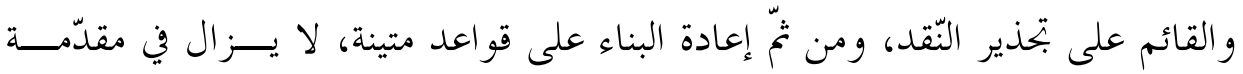

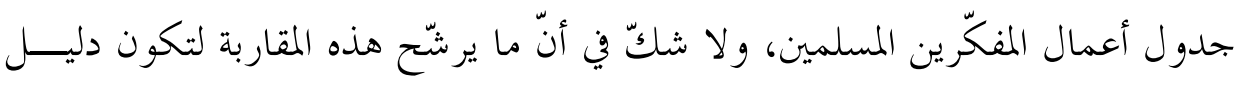

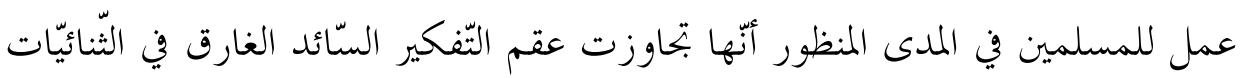

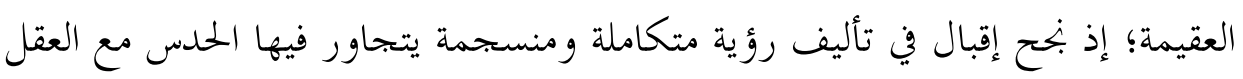
و الفلسفة مع الدّين و الرّوح مع المادّة.

ويحوج الحوض في هذا الإشكال، إلى مر اجعة إستراتيجيّة إقبال في تطويسـع مبــــأ

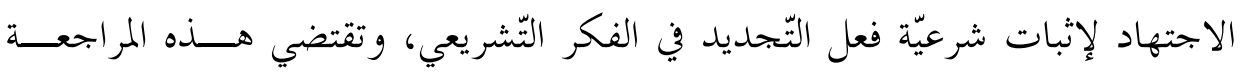

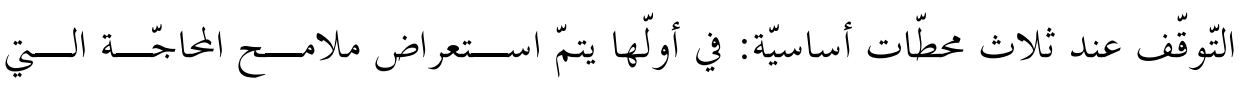

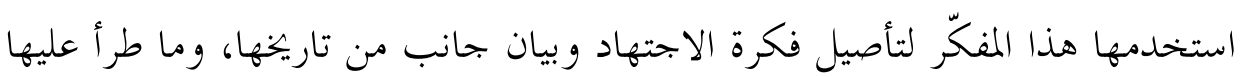

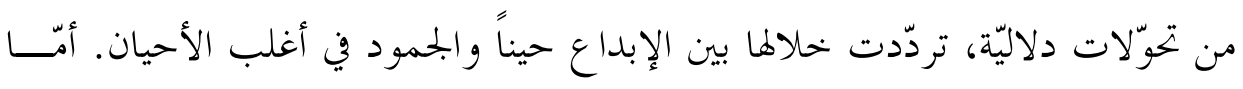

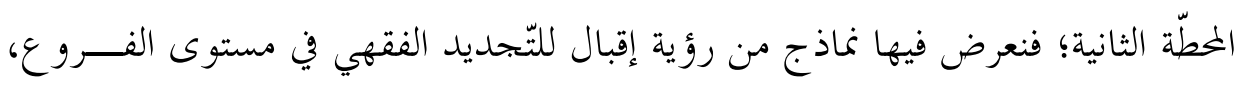

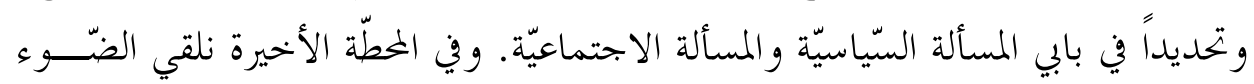


على الإضافة النّوعيّة التي تقدّم هها إقبال لتجديد أصول الفقه، تلـــك الإضـــافة الـــيت استقامت على كشف ما تنطوي عليه المبادئ الأصولّية من ممكنات التّجديد.

\section{أوّلاً: الاجتهاد في التّاريخ، من الحر كة إلى السّكون}

لما كان أكثر المهتمّين بتاريخ الفقه من أهل الاختصاص، فإنّ رواية الحوادث فيسـه

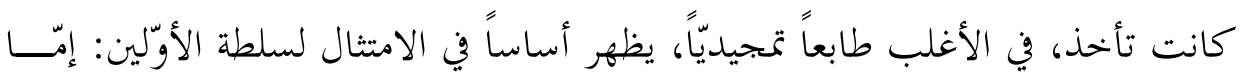

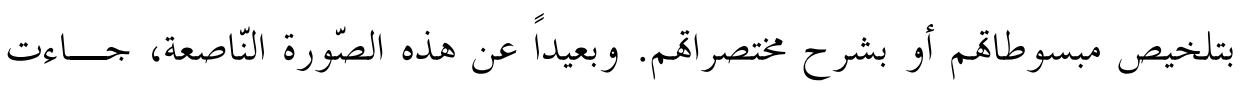

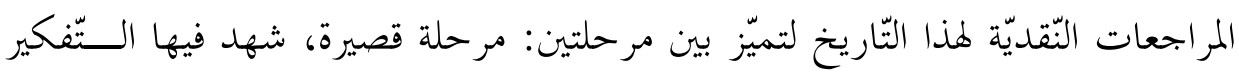

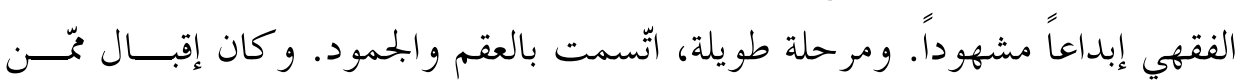
صادقوا على هذا التّقويم النّقدي لتاريخ الفقه الإسلامي.

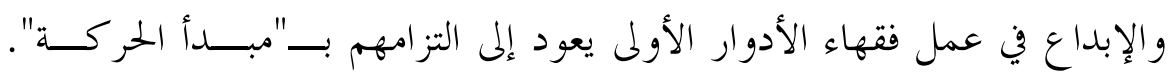
و كان لهذا الالتزام عنو ان محدّد هو : "الاجتهاد". ويبدو أنّ تقدير إقبال للمكانة المركزيّة

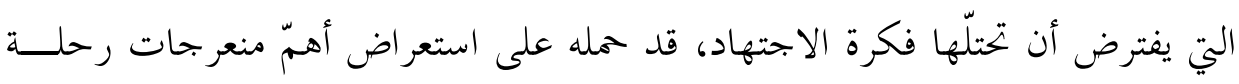
هذا المفهوم في تاريخ التّشريع الإسلامي، و كانت الغاية تتجاوز بحرّد الرّصد إلى التّقويم

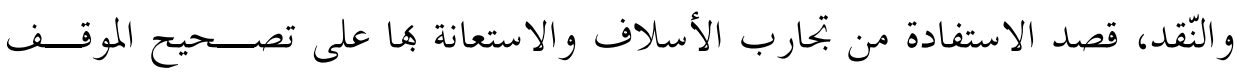
الحديث.

\section{ا ـ الاجتهاد بين غياب النصّ وحضوره:}

حفلت كتب القدامى بتعريف لفظ الاجتهاد، وذهبت فيه مذاهب مختلفة بحسب

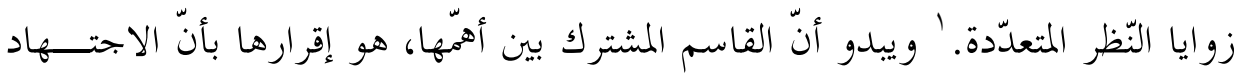
يقوم على "بذل الوسع" في استنباط الأحكام. وقد شبّه الغزالي اســتنباط الأحكـــام

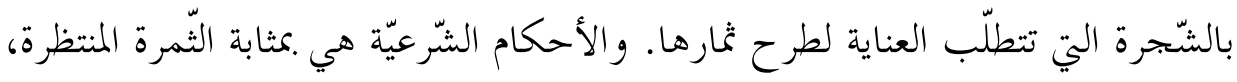

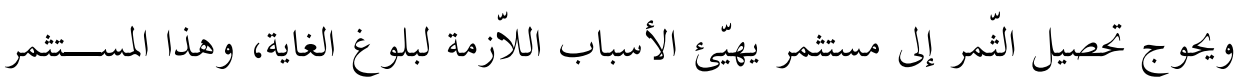

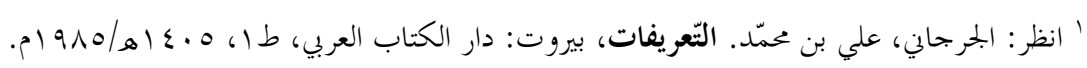




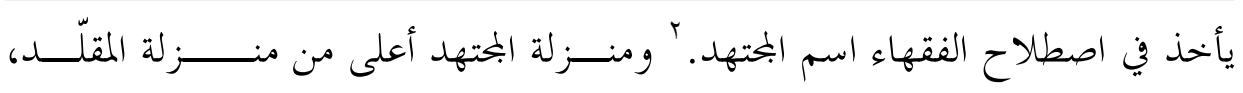
الذي لا يبذل وسعه في استخراج الأحكام، بل يكتفي باتّباع أقو ال غيره من البحتهدين.

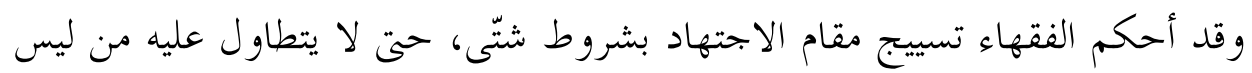

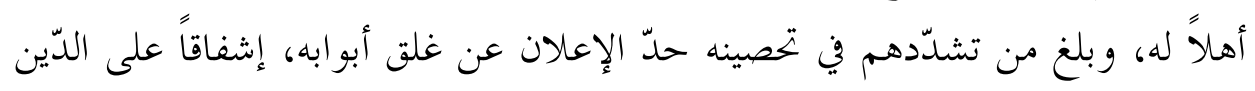
من أن يدخل فيه من الأحكام ما ليس منه.

و يبدو أنّ معنى الاجتهاد، قد خضع لتعديلات تغيّرت بموجبها مضامينه، و الأرجح

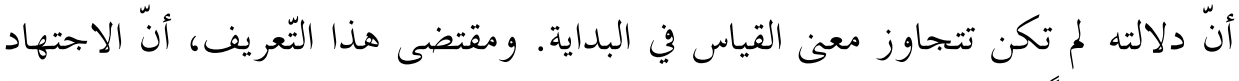

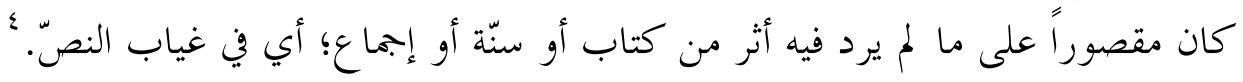

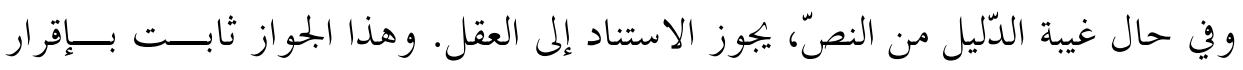

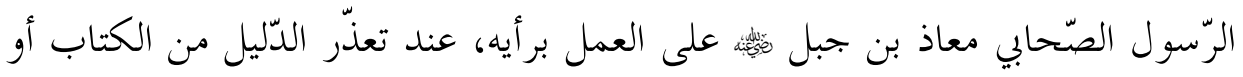

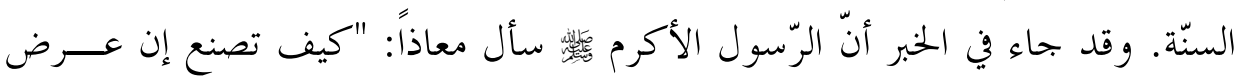
للك قضاء؟ قال: أقضي .بما في كتاب الله. قال: فإن لم يكن في كتاب الله؟ قال: فبسنّة

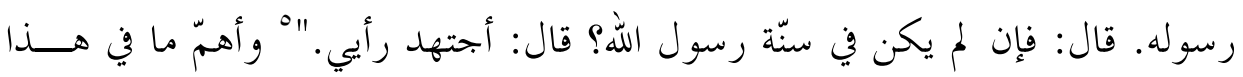

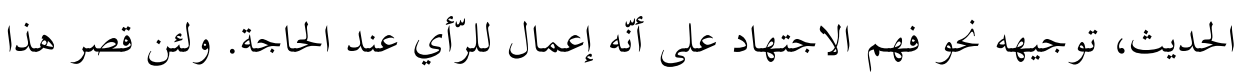

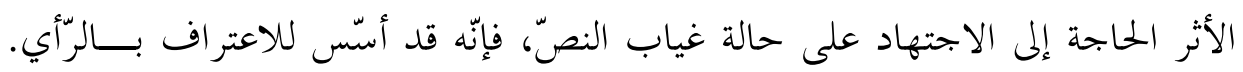

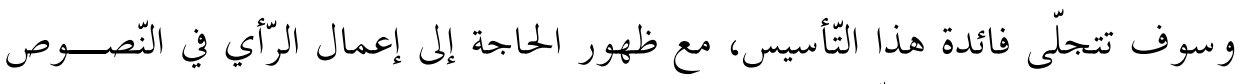

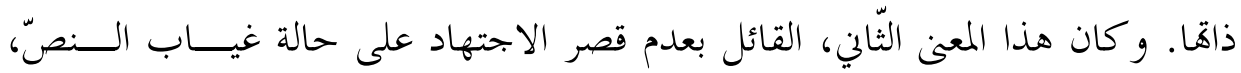
حاضراً في ذهن إقبال، وهو يراجع تاريخ التّشريع الإسلامي. الماني.

ب الغز الي، أبو حامد. المستصفى من علم الأصول: تحقيق: محمّد سليمان الأشقر، بــيروت: مؤسّســة الرّســالة،

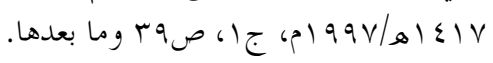

: انظر

- Wael B . Hallaq, "Was the gate of Ijtihad closed", International Journal of Middle East Studies, vol. 16, N. 1, March 1984.

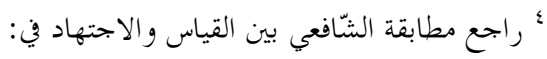

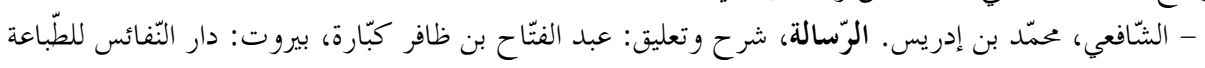

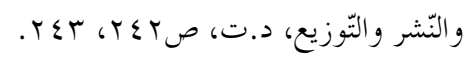

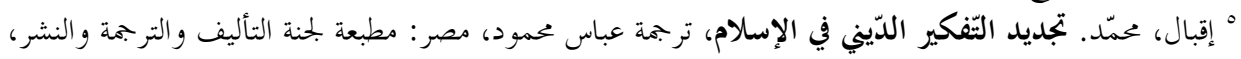




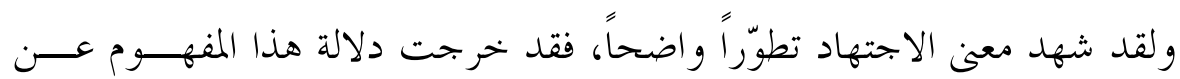

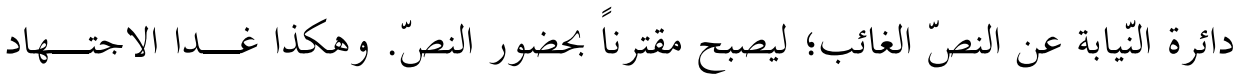

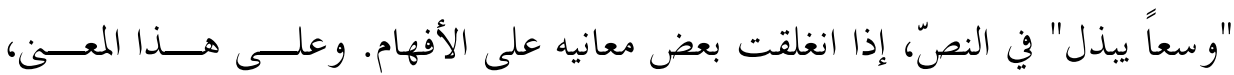
استقرّت دلالة الاجتهاد.

و لم يخرج إقبال عن سنّة من سبقوه في الحثثّ على العمل بالاجتهاد. و الذي ميّــز

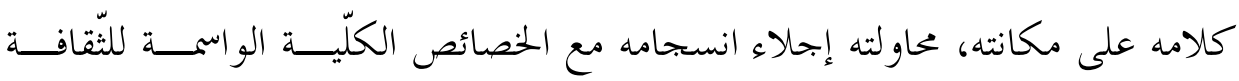

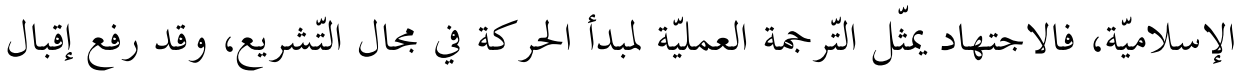

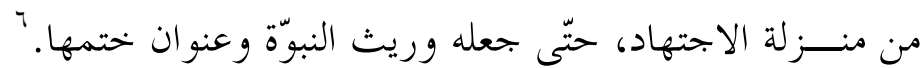

و الذي ميّز مقاربة إقبال لمسألة الاجتهاد طابع التسهيل والتّلقائيّة، فقد اكتفـى في بيان حدّه بإبراز عنصرين، أوّلاً: بذل الوسع، باعتباره قاعدة المفهوم الأساسيّة. وثانياً:

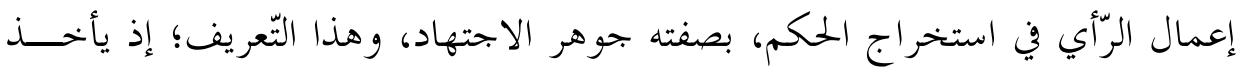

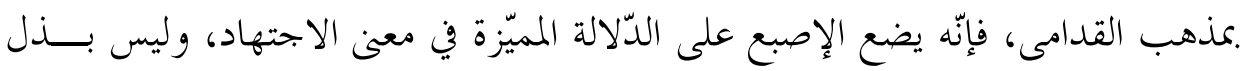

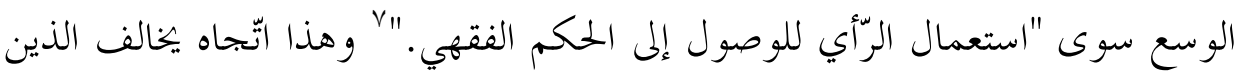
يقصرون بذل الوسع، على تقليب النّصوص وعرض بعضها على بعض.

و يبدو أنّ إقبال قد استشعر خطورة ما قرّره بخصوص ربط فعل الاجتهاد بإعمال العقل، فعمد إلى تأييد موقفه بحجج لا يرقى إليها الطّعن. وقد اختار من القرآن، الآية:

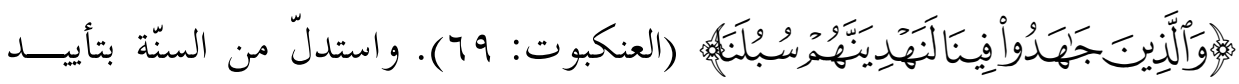

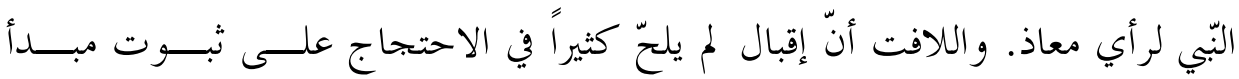

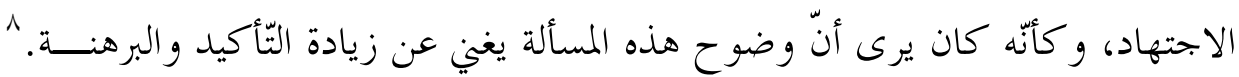

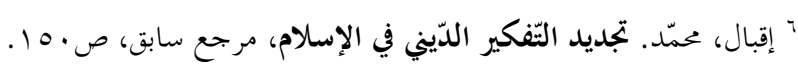

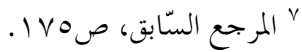

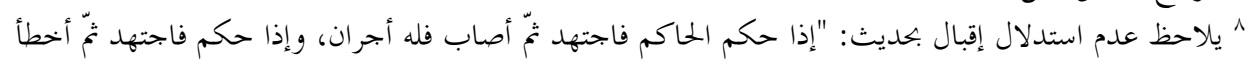

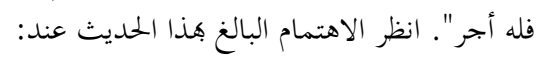

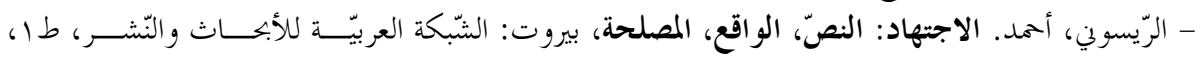


ولكنّ بحادلات المسلمين بخصوص تحديد المقصود بالاجتهاد أعقبتـــها ردود مطوّلـــة

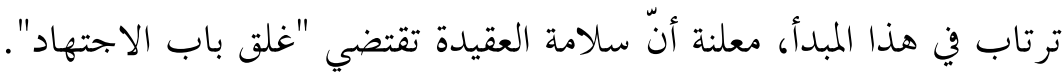

\section{Y. الاجتهاد في التّاريخ بين القيد وفكّ القيد:}

لا خحلاف على أنّ الاجتهاد أصل ثابت في الإسلام عند أكثر المسلمين؛ إذ سلّموا به على الصّعيد النّظري وعملو ا به على تفاوت بينهم. وقد كانت له عنـــدهم ثــلاث مراتب: أعلاها، الاجتهاد التامّ، وأوسطها الاجتهاد النّببي، وأدناها الاجتهاد الخاصّ.

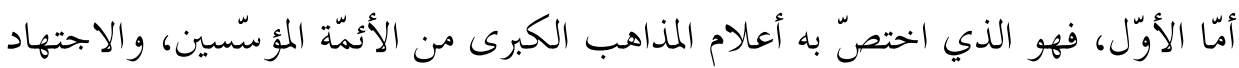

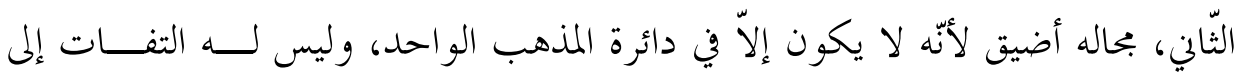

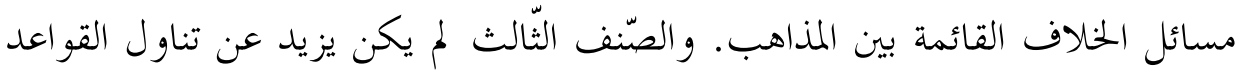

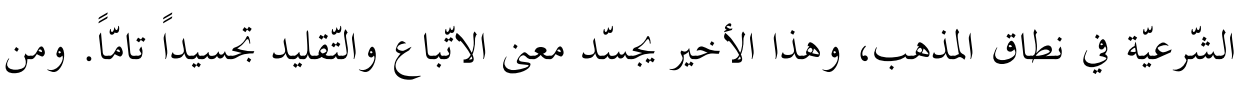

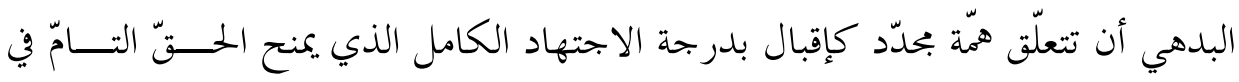

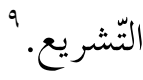

ومن موقع الانتساب إلى دائرة الاجتهاد الكامل، و وجّه إقبــــال نقـــــه للفقهــــاء

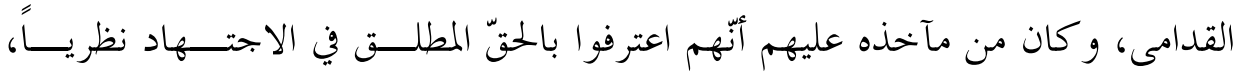

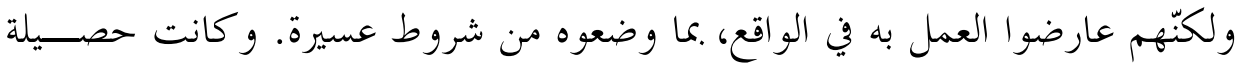

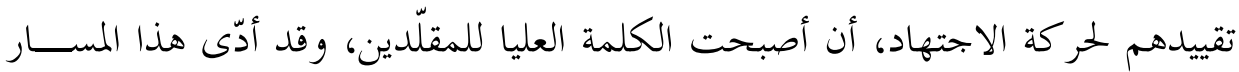

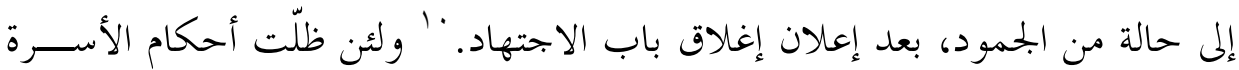

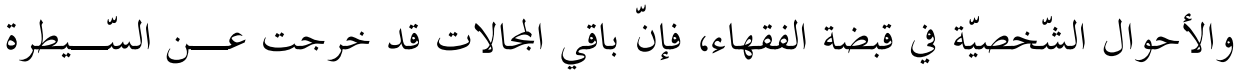

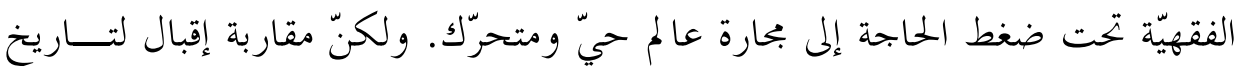

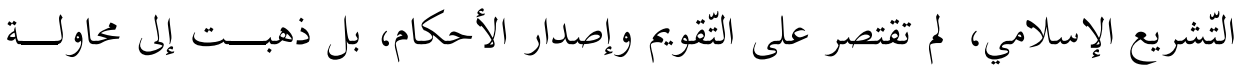

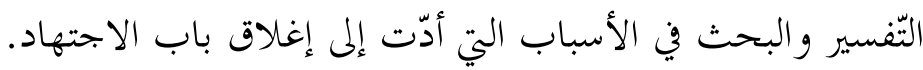

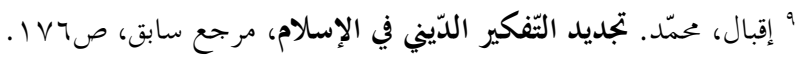

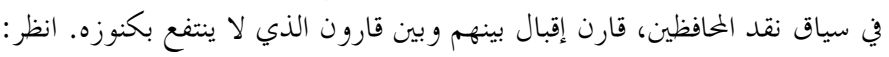

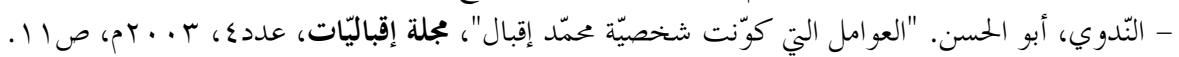


و في تفسير أسباب انقطاع حركة الاجتهاد، ذكر إقبال ثلاثة عو امــل أساســيّة،

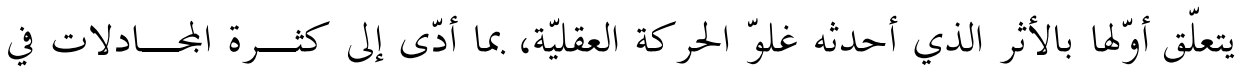

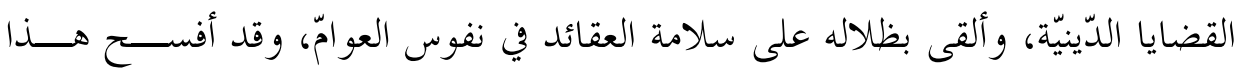
الوضع الباب أمام التّّار المحافظ ليحدّ من مساحات حرّية التّفكير. ويعود العامل الثّاني

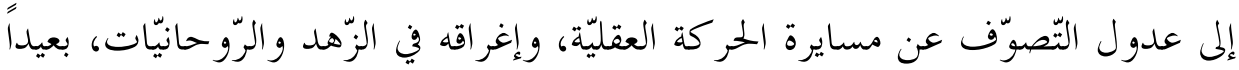

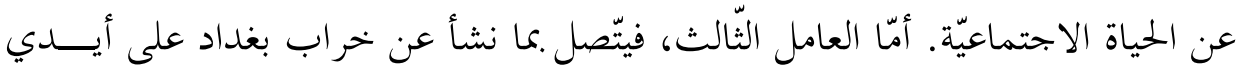

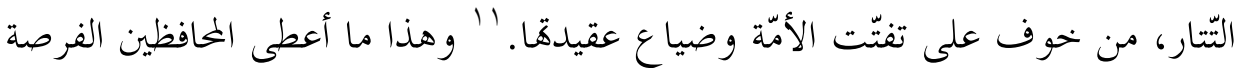

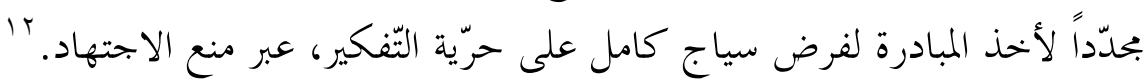

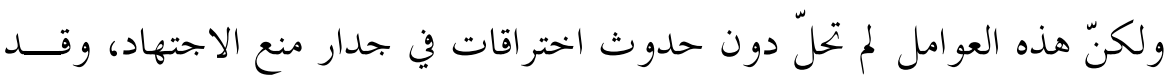

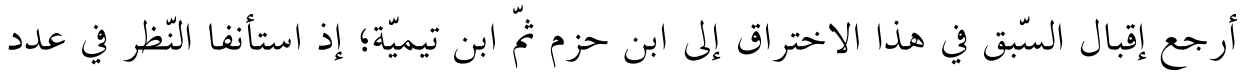

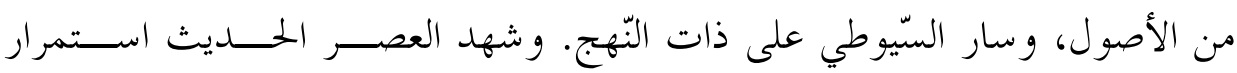

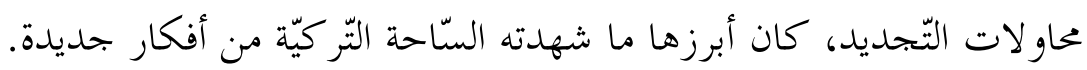
ولئن أشاد إقبال بجهود هؤلاء المحدّدين قديماً وحديثاً، فإنّنه لم يتحدّث عن مضامين

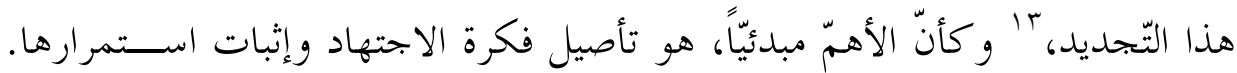

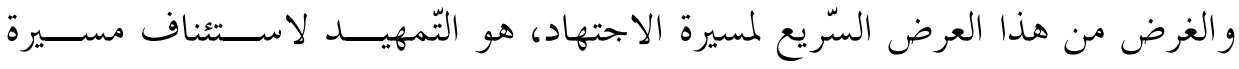

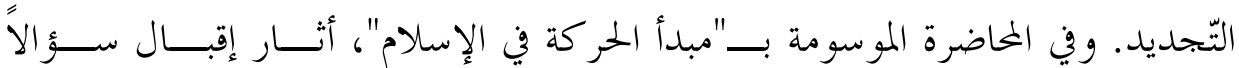

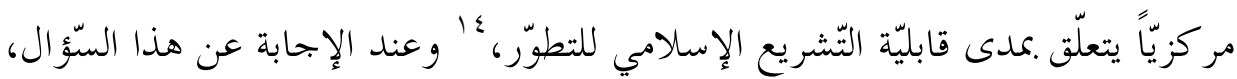

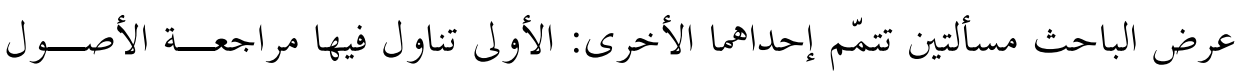

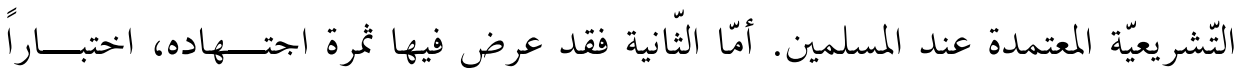

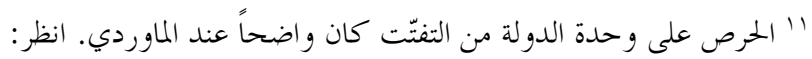

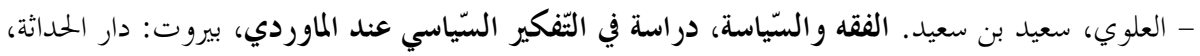

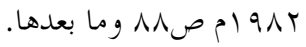

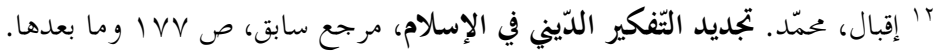

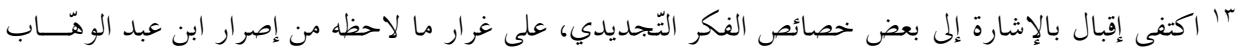

$$
\begin{aligned}
& \text { على الحقّ في الاجتهاد. انظر: }
\end{aligned}
$$

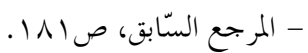

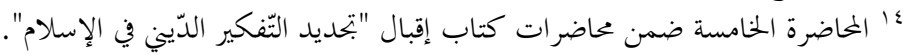


لصحّة مر اجعته لتلك الأصول. و وارتأى أن يعالج من مسائل الفرو ع، أكثرها إلحاحاً في التّاريخ الحمديث، و نعين بذلك المسألة السيّيسّة و المسألة الاجتماعيّة.

\section{ثانياً: الاجتهاد بما هو مهمّة عاجلة: تجديد الفرو ع الحاكمة}

ترجع بعض الدّراسات بدء حر كة التّجديد في مسائل الفروع الفقهيّة، إلى ظهور

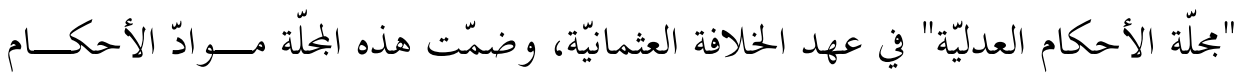
الفقهيّة المعتمدة عند أتباع المذهب الحنفي. أمّا من جهة المضمون؛ فأوّل ما اهتمّ هؤلاء الفقهاء بتجديده، كان أحكام المبادلات التّاريّة، وذلك بسبب تأكّد الحاجة إليها في المعاملات الحيويّة. مُ واتّسعت حركة التّجديد الفقهي بالتّدريج، و كان تدوين الدّساتير في مقدّمة شواغل المهتمّيّن بالفكر القانوني، منذ منتصف القرن التّاسع عشر . 17.

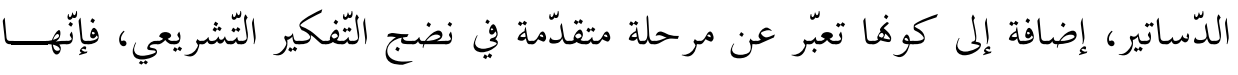

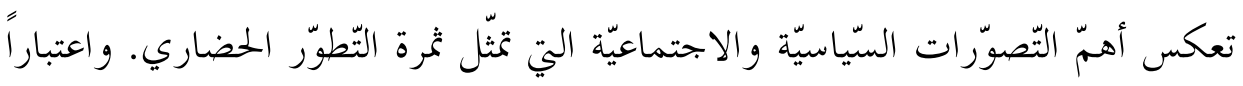
للظرف الدّقيق الذي ينجز فيه مشروع التّجديد، فإنّ الاجتهاد ينبغــي أن يتّجــــه إلى

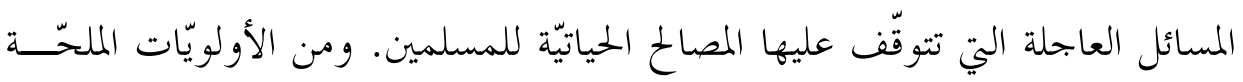
التي اهتمّ إقبال ببحثها قضية الحلكم، .ما هي أصل الفكر السّياسي.

\section{ا ـ مسألة الحكم و النّموذّ ج التّركي:}

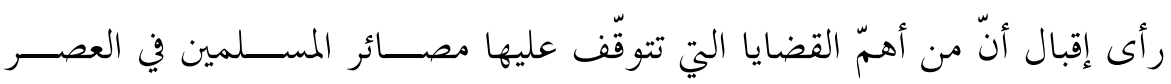

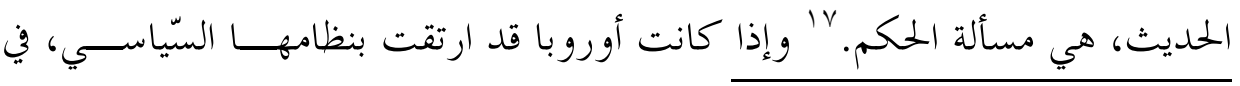

ما انظر ما ذكره جوزيف شاخت في هذا المعنى، خاصّة في وسم قو انينها بالعلمانيّة:

- " L'expérience de la Mejelle fut tentée sous l'influence d'idées européennes, et à proprement parler, c'est un code laïc et non islamique", Joseph Schacht, Introduction au droit musulman, G.P. Maisonneuve et Larose, 1983, p 81.

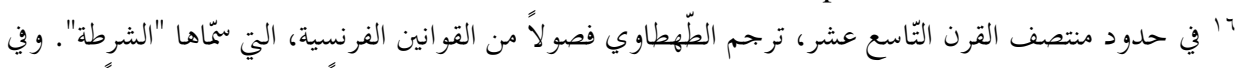

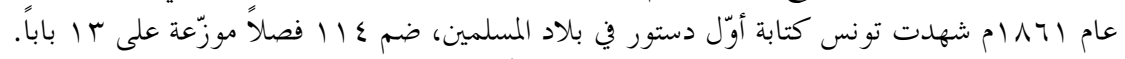

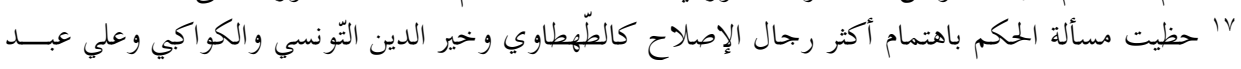

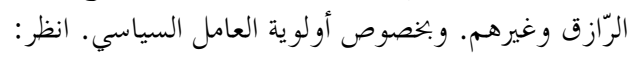




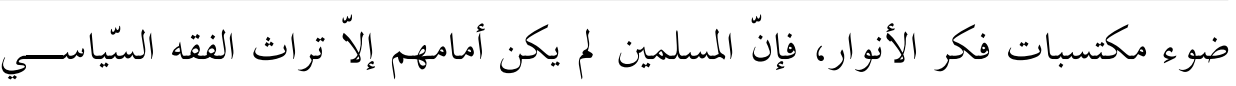

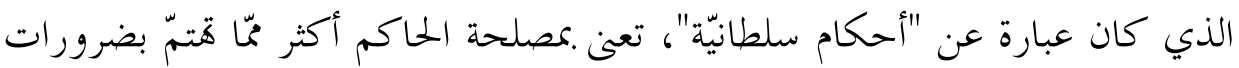

ولكنّ الشّروط التي خضع لها الماوردي وأمثاله قد تبدّلت، وأصبح من الضّروري

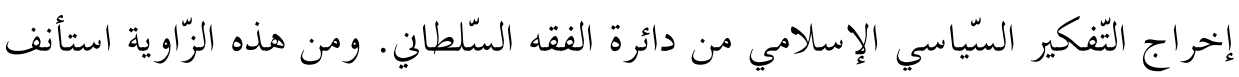

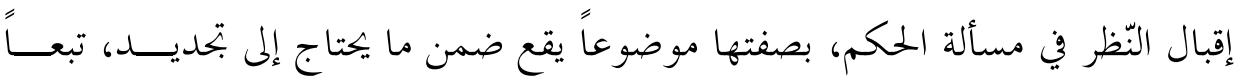

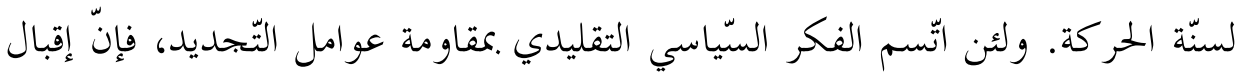

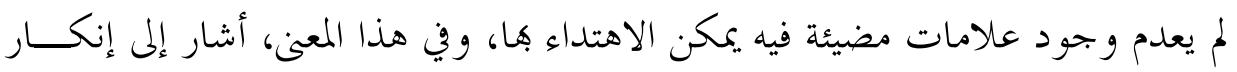
الباقلاني وابن خحلدون لشرط القرشيّة في منصب الإمامة.

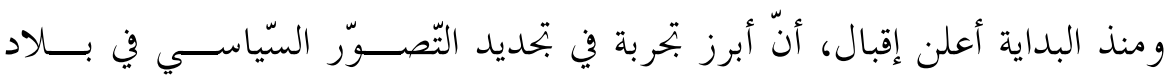

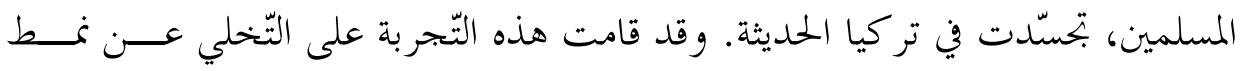

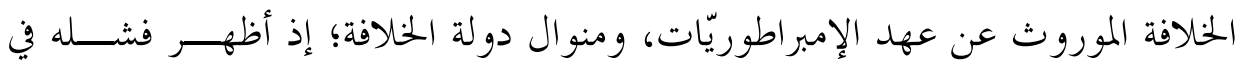

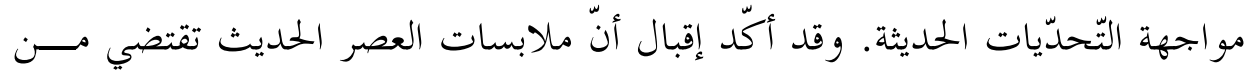

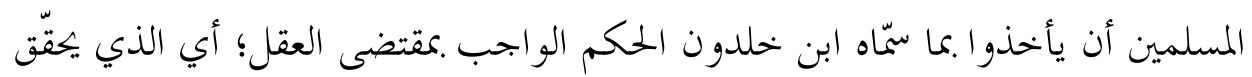

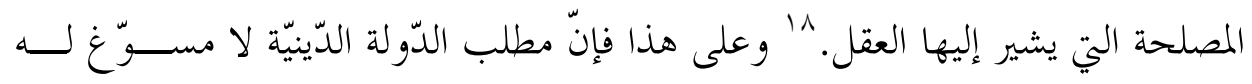

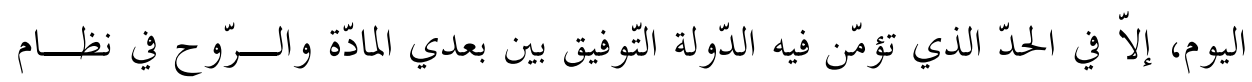

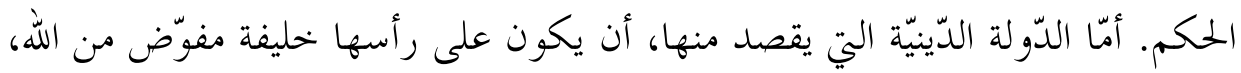

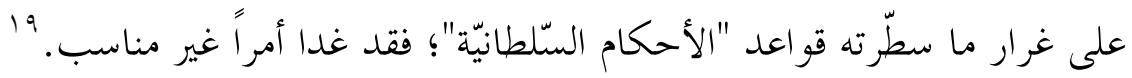
ونظريّة الحكم المستمدّة من روح الإسلام، جاءت لتقطع مع التّجربة المسيحيّة التي

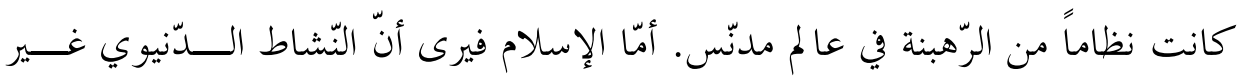

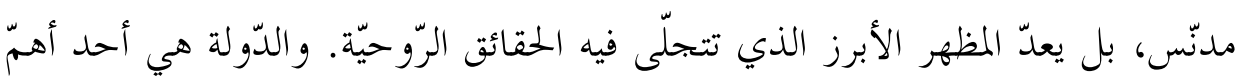

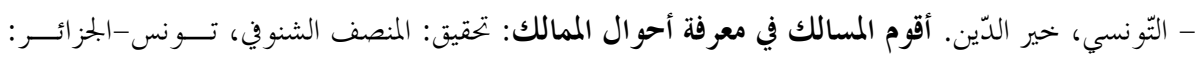

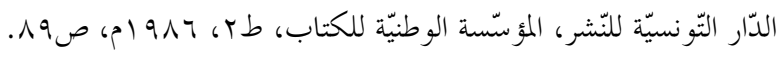

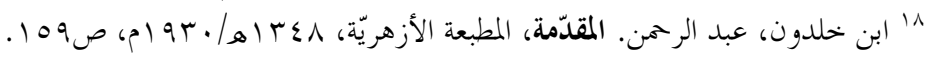

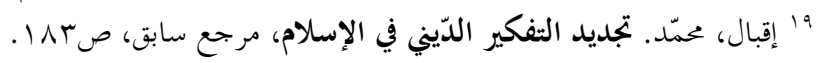


الأجهزة القائمة على تنظيم هذا النّشاط، فهي الحامل للجوهر الرّوحي في شتى نواحي

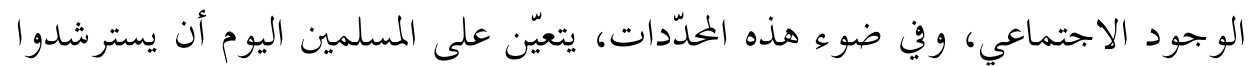

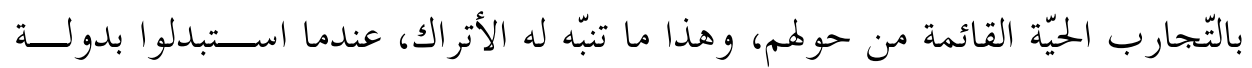

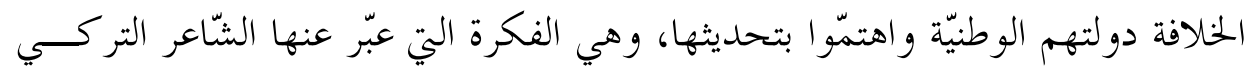

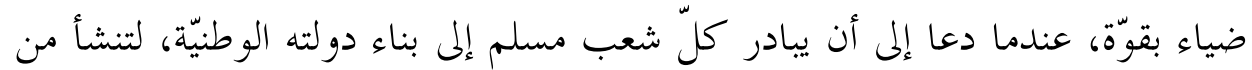

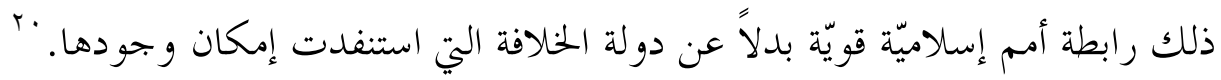

وإذ نظر إقبال بإعجاب إلى آراء هذا الشّاعر، وأيّده فيما ذهب إليه بخصوص عدم

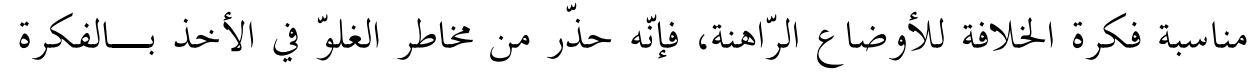
القوميّة، التي كان يصدر عنها الأتراك في مشروعهم الإصلاحي، وقد بلغ من ريبته في

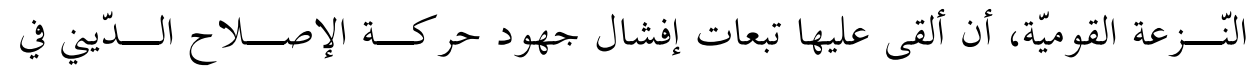
أوروبا، ومن المرجّح أن يكون و اقع تعدّد القوميّات في الهند، وراء ارتياب إقبــــال في إِي

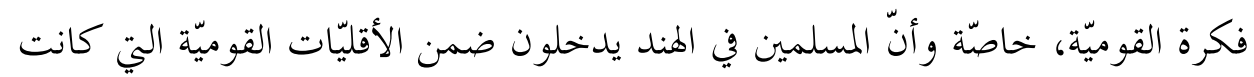
تعاني من سيطرة الهندوس وقوّة نفوذهم في البلاد.

وهكذا هض بتحيد التّفكير السّياسي عند محمّد إقبال، على معارضة مشروع إقامة

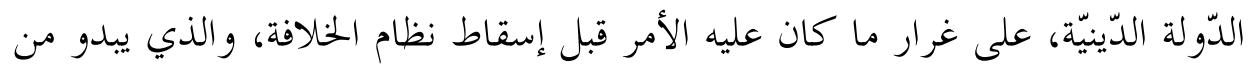

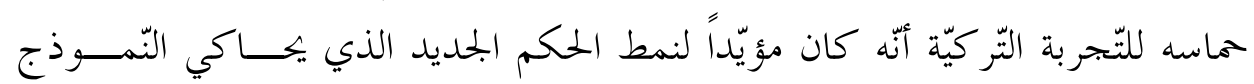

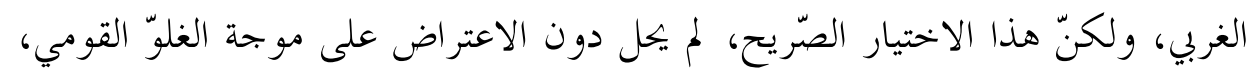

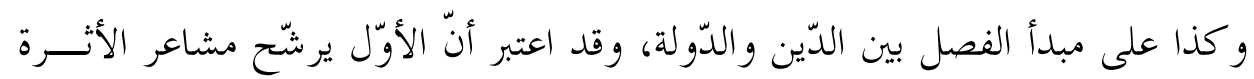

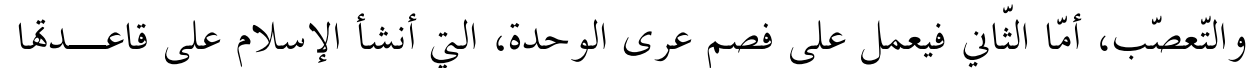
الكيان الإنساني.

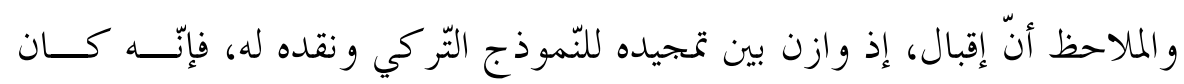

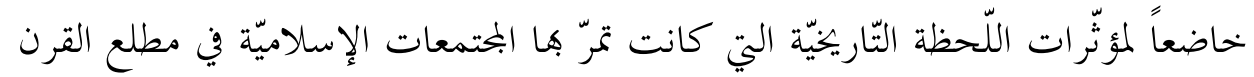




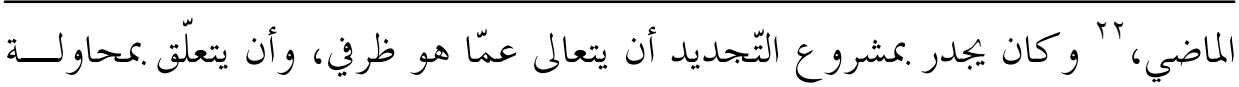
اكتشاف القواعد الثّابتة التي يمكن أن ينهض عليها إصلاح الحكم في بلاد المســلمين.

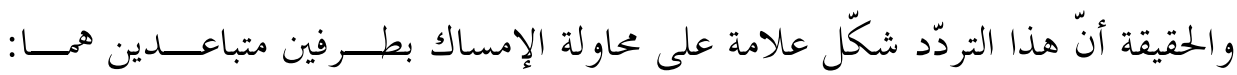

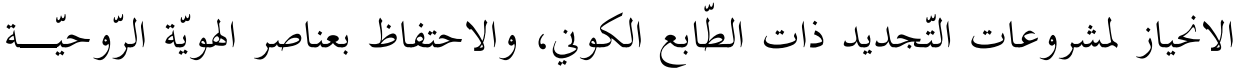

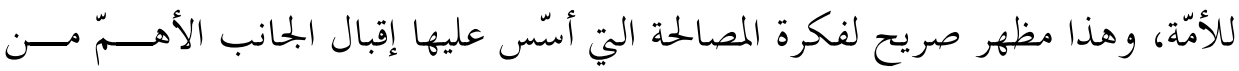
مقاربته التّجديديّة.

إنّ انخراط إقبال في الدّعوة بحماس إلى بتحيد التّفكير السّياسي، لا يعني القطع مع

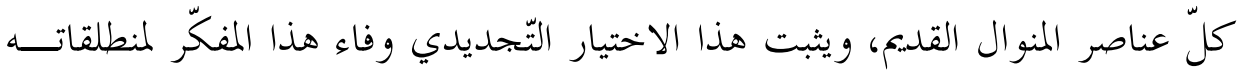

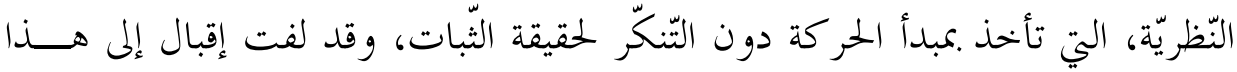

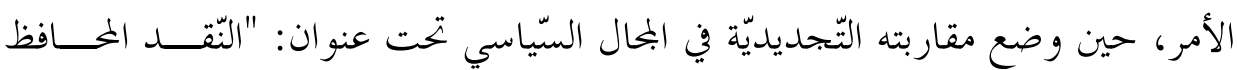

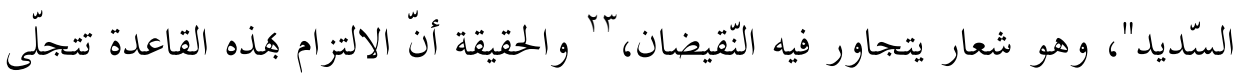

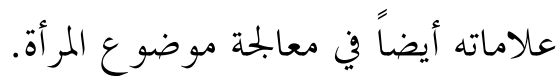

\section{Y ب. المسألة الاجتماعيّة: قضية المرأة:}

شغلت قضيّة المرأة جانباً من الخطاب الإصلاحي، منذ أواخر القرن التّاسع عشر.

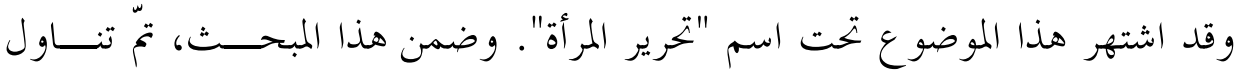

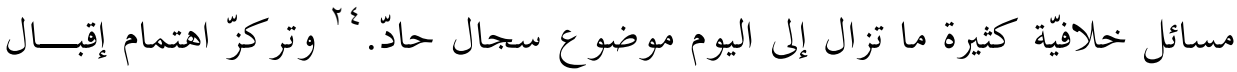

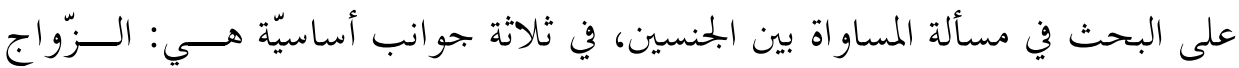

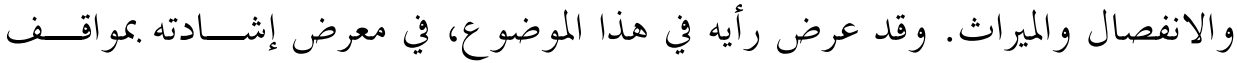

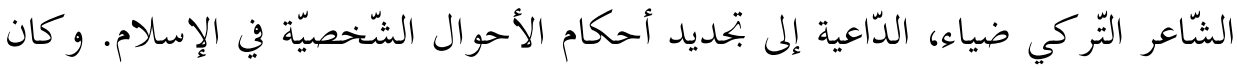
منطلق هذا التّكير، أنّ حركة الإصلاح ينبغي أن تبدأ بتحرير الأسرة من قيود العو ائد الديد البالية التي تكرّس ظلم المرأة.

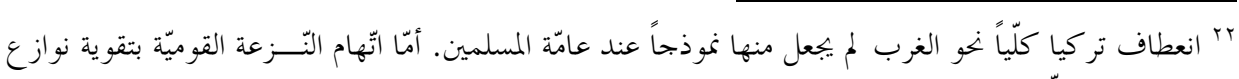

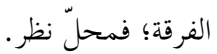

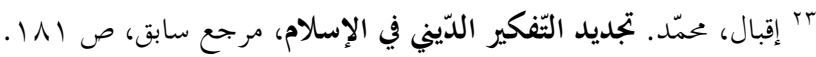

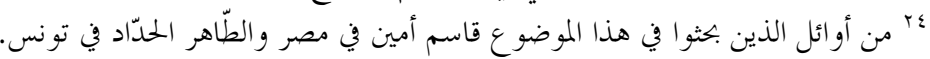


و يبدو تأييد إقبال لآراء الشّاعر التّركي، في إلحاحه على تأكيد الطّابع المدني لعقد

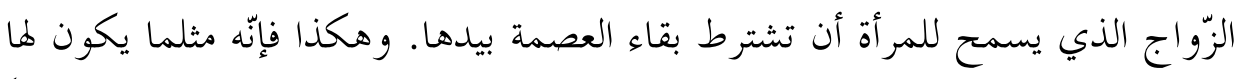

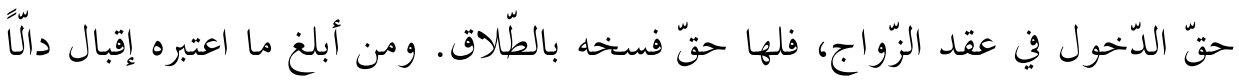

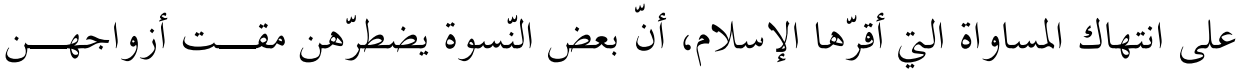

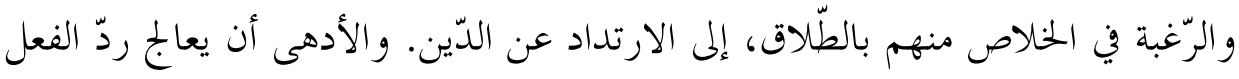

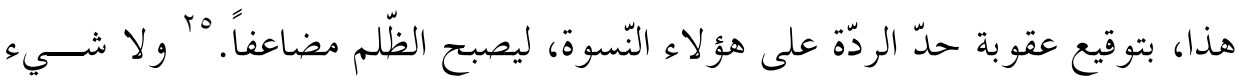
أبعد من كلّ هذا عن روح الإسلام.

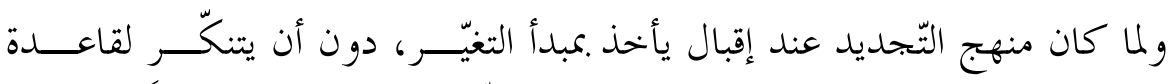

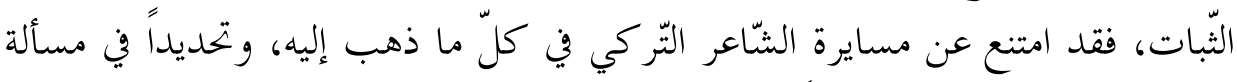

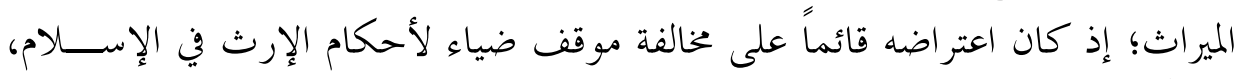

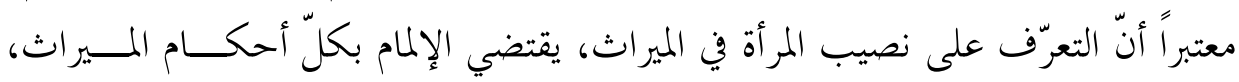

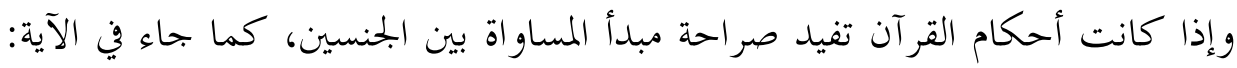

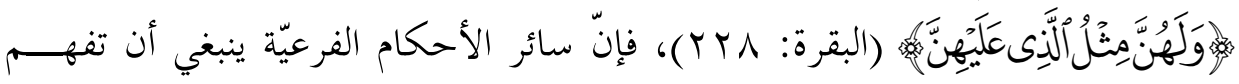
ضمن هذا المبدأ العامّ.

و الواضح أنّ إقبال كان يميل إلى الاقتصاد في إبداء آرائه، ومن ذلك أنّه لم يتطرّق

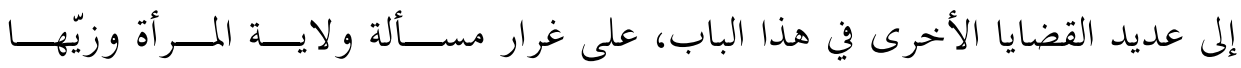

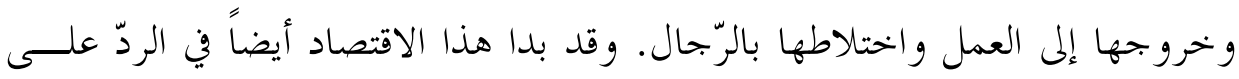

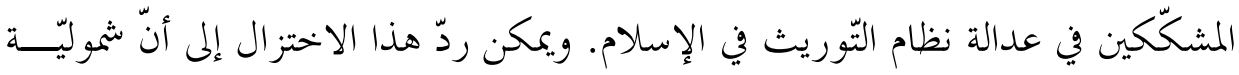

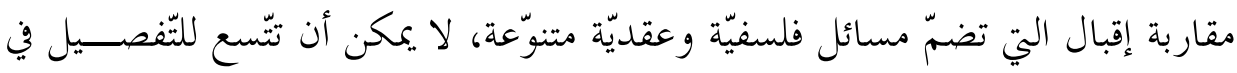

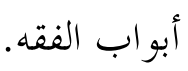

و الثّابت أنّ دائرة الاجتهاد عند إقبال ظلّت محكومة معحدّدين اثنين: محدّد فلسفي

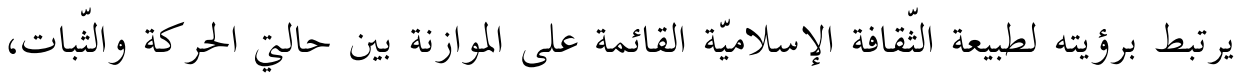

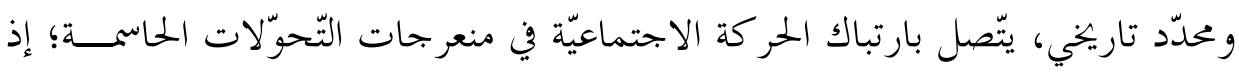

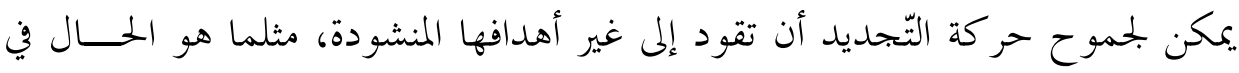




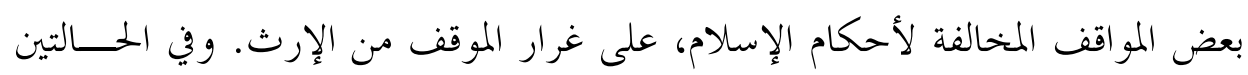

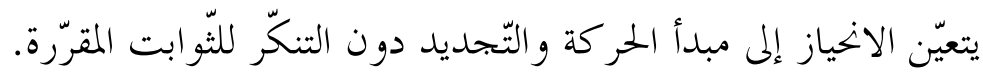

وإذ اكتفى إقبال هذذه الإشارات السّريعة، فإِّه أكّد أنّ إمكانيّات التّطوير الكامنة

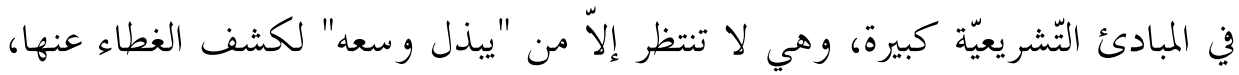

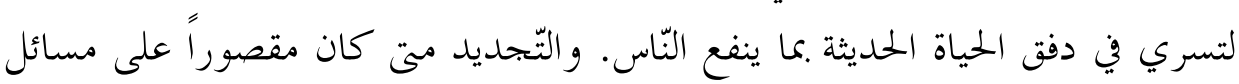

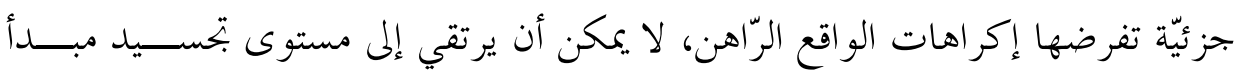

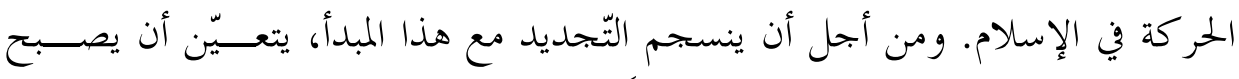

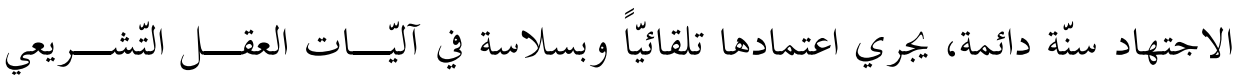

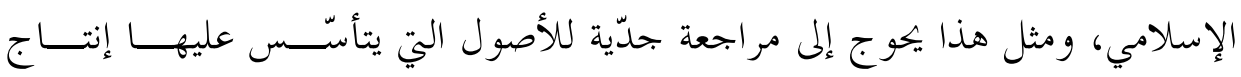

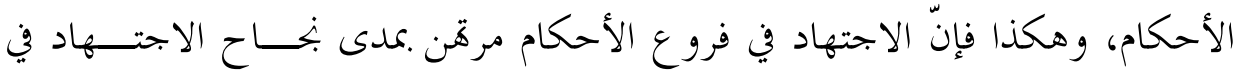

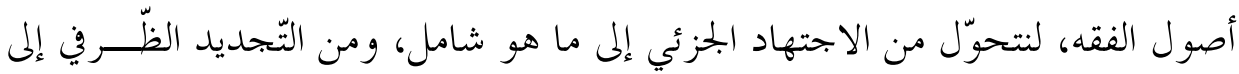

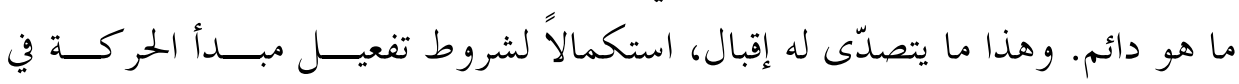

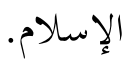

ثالثاً: الاجتهاد بما هو مهمّة دائمة: تجديد القاعدة

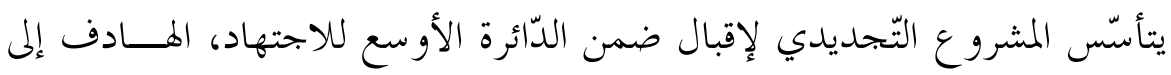

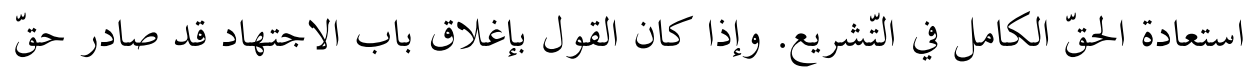

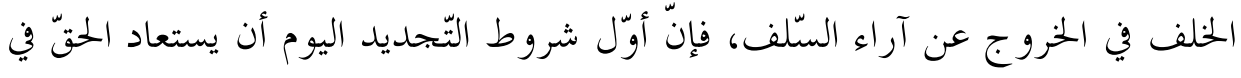

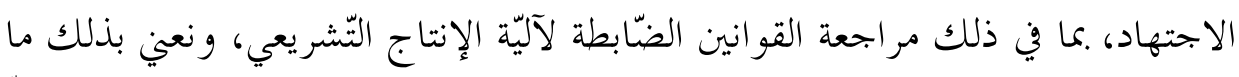

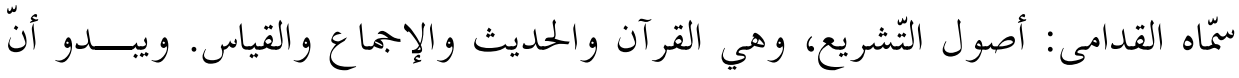

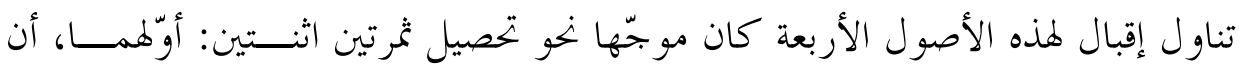

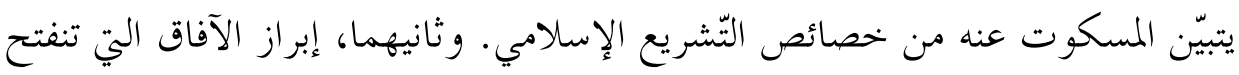

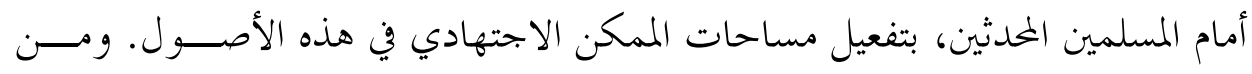

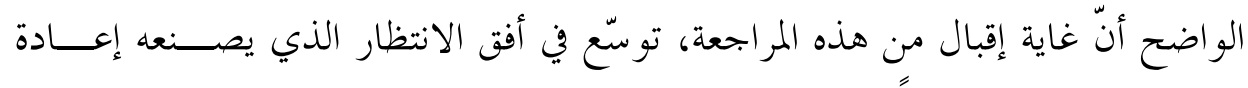
تنصيب الاجتهاد حاكماً في حياة المسلمين. 


\section{1 ا ـ الخصائص التّشريعيّة: المسكوت عنه في الأصول:}

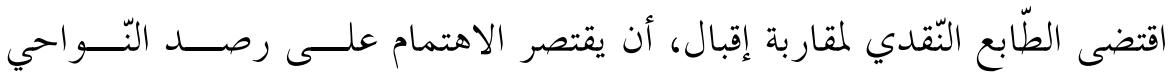

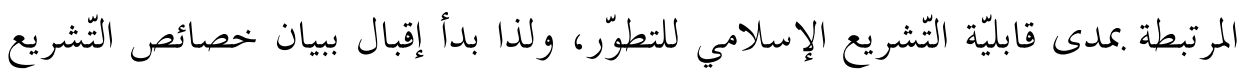

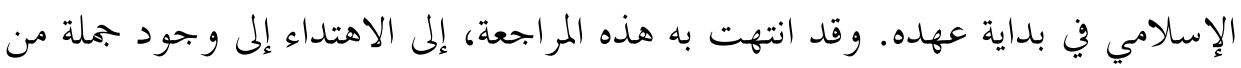

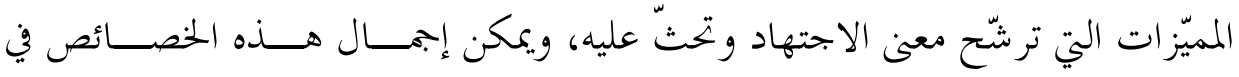

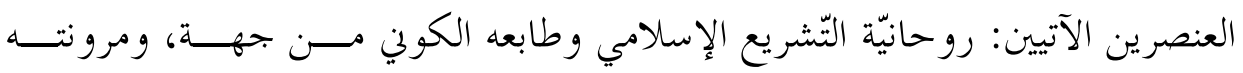

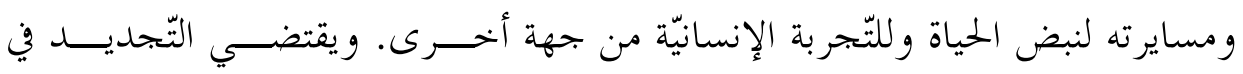

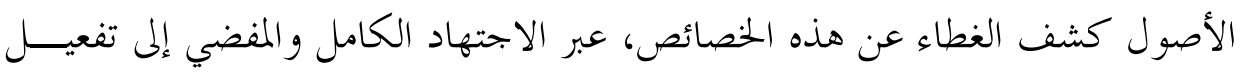

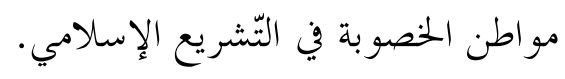

\section{أ. روحانيّة التّشريع وطابعه الكولي:}

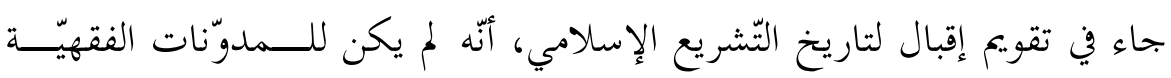

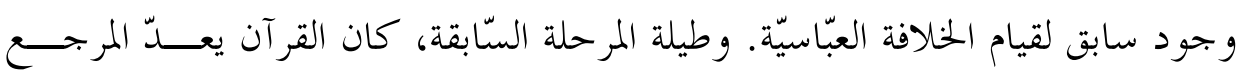

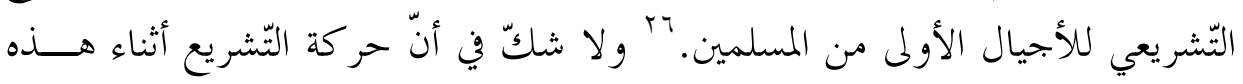

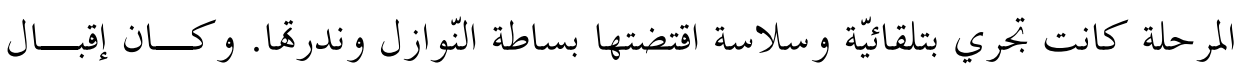

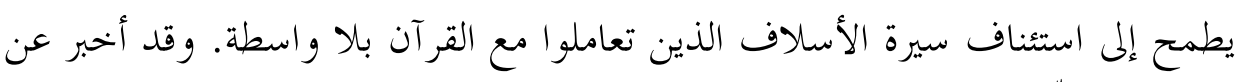

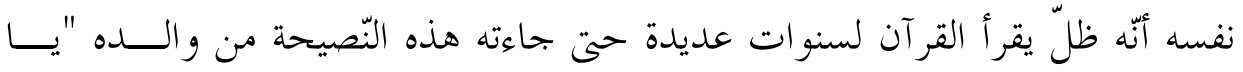

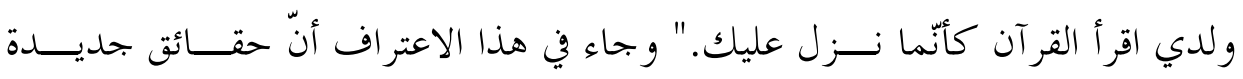

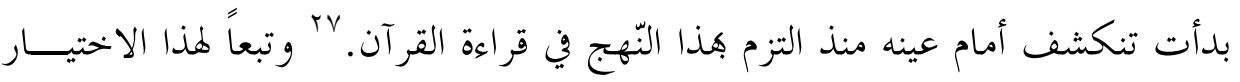

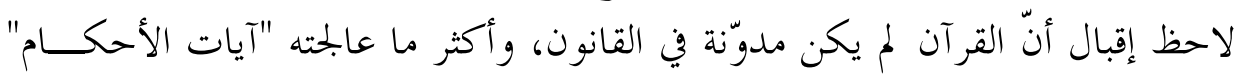

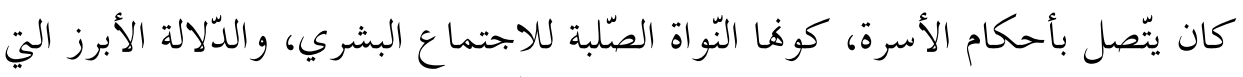

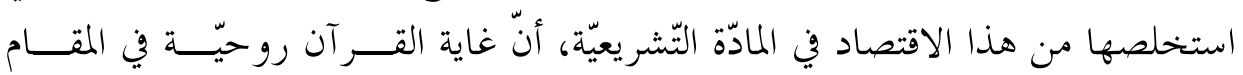

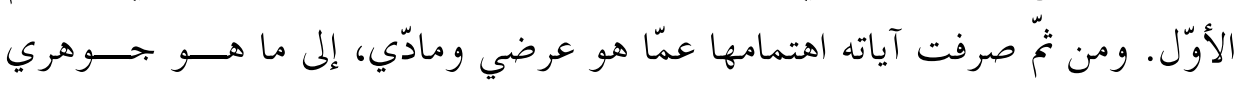




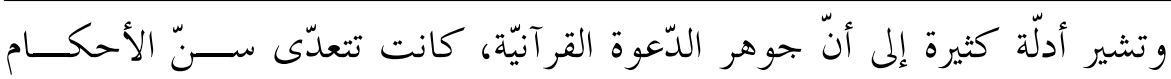

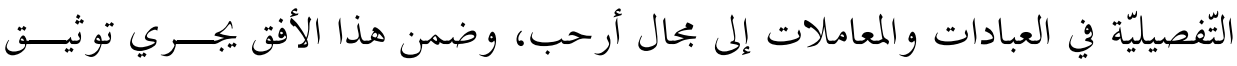

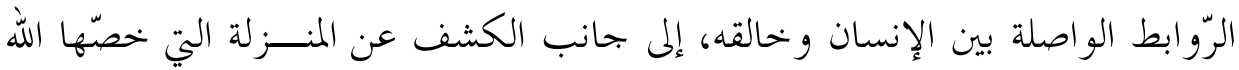

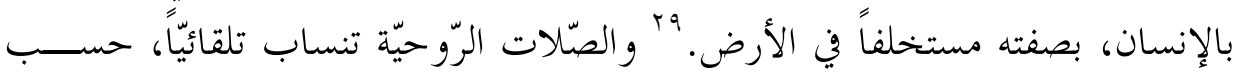

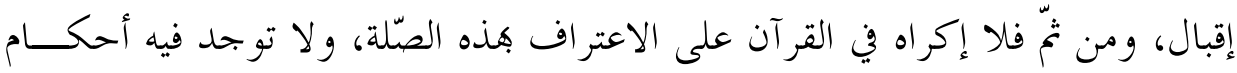

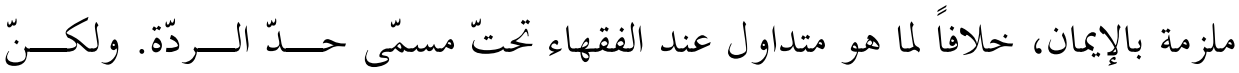

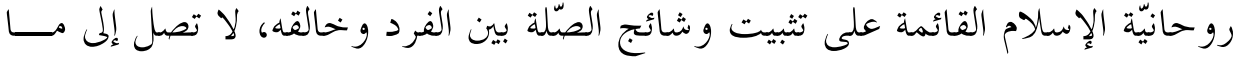

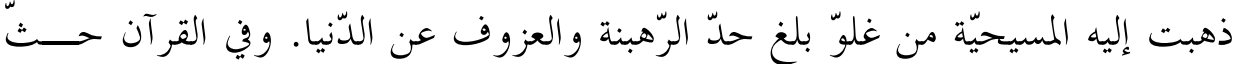

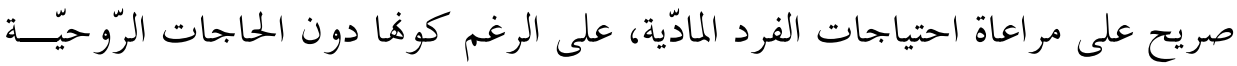
مكانة.

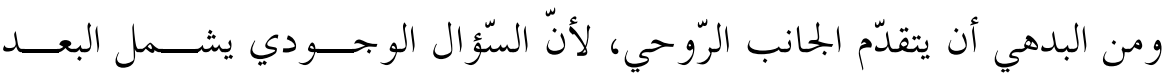

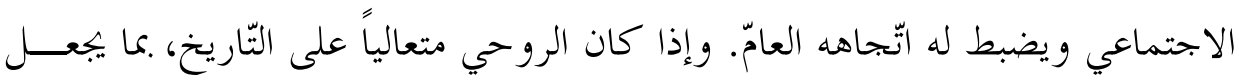

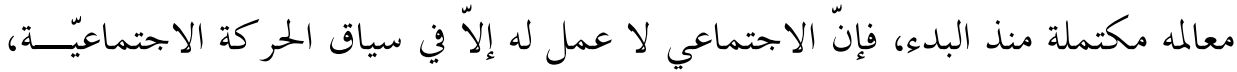

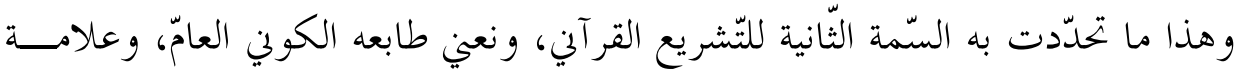

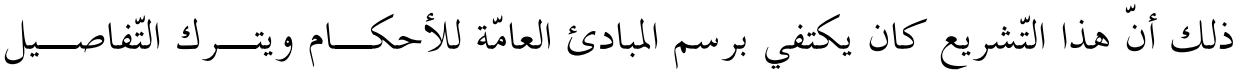
للاجتهاد البشري، وقد و جد إقبال هذا المعنى في واحد من أهمّ المفــــاهيم الإســـالاميّة،

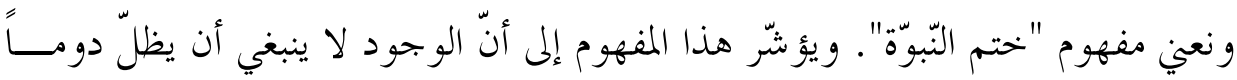

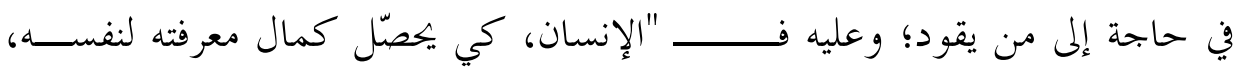

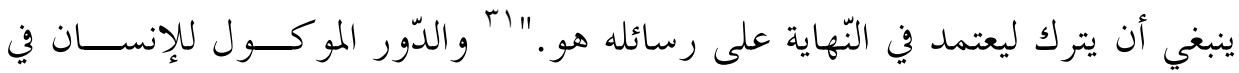
الوجود هو موضوع وظيفة الاستخلاف.

و في الأصل الثّاني من أصول التّشريع الإسلامي؛ أي الحديث النّبوي ما يقيم الدّليل على هذه الحقيقة، ولئن كان ظاهر التّشريع النّبوي، أنّه يرتبط بوقائع محليّة -النّــــوازل

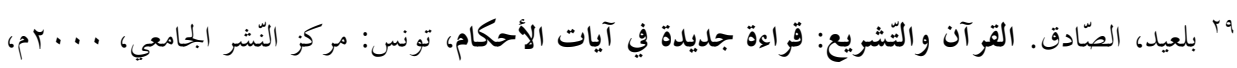

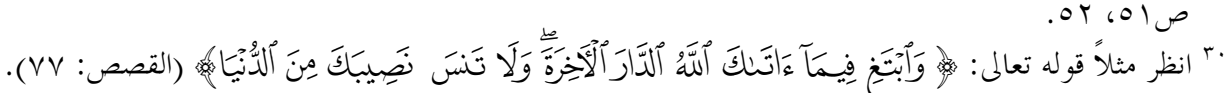

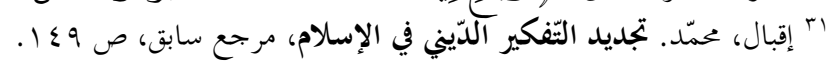




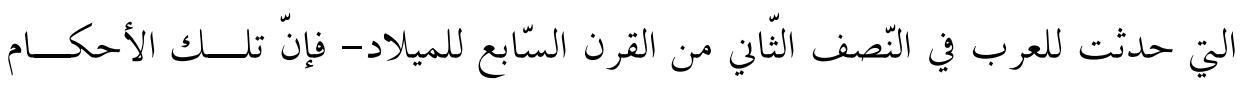

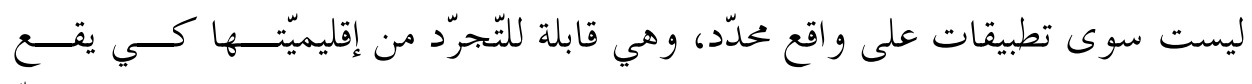

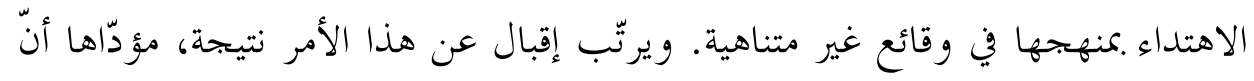

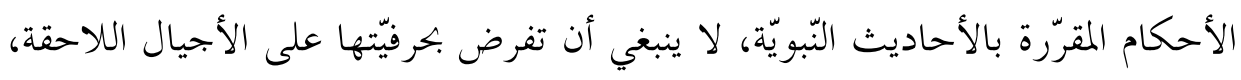

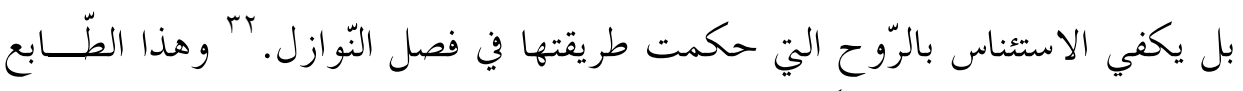

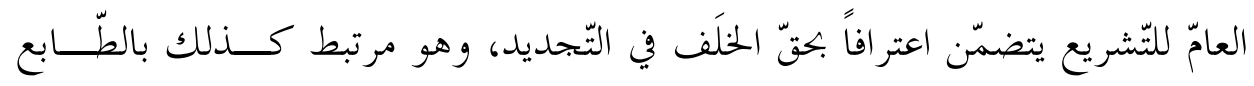

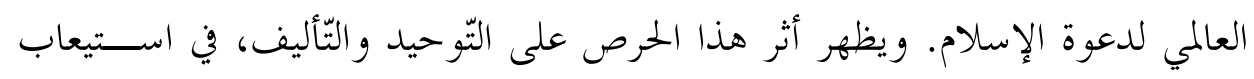

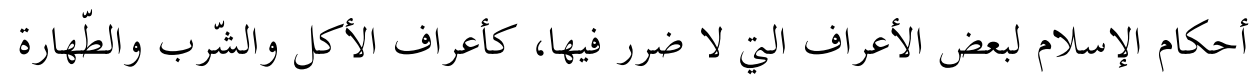

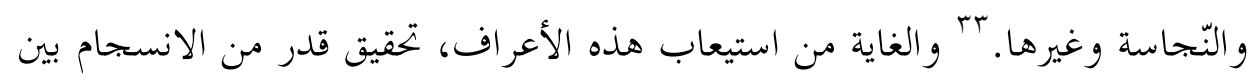
الجماعات المتنافرة والمتنافسة.

وقد كان الوعي بأنّ الإسلام دين غير إقليمي، وراء ميل أبي حنيفة إلى الأخذ .مبدأ

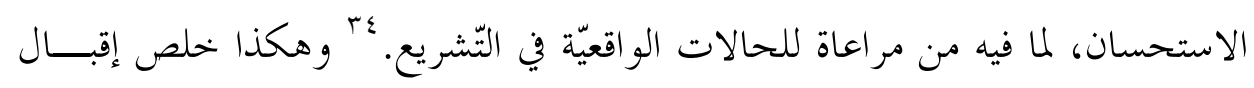

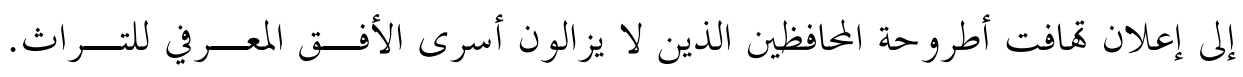

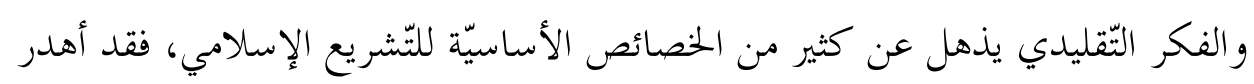

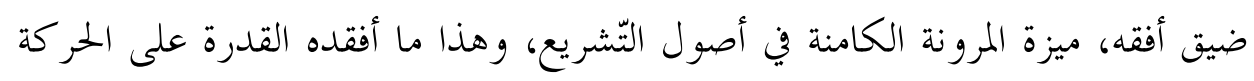
و التّطوّر.

\section{ب. مرونة التّشريع وارتباطه بالتّجربة:}

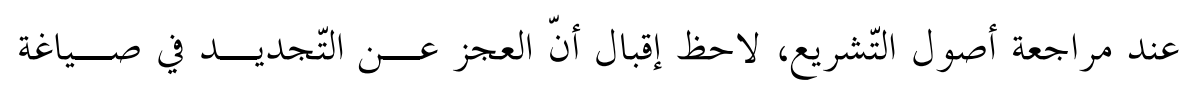

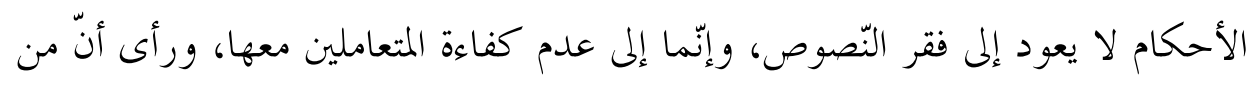

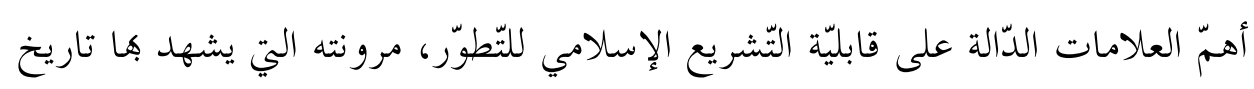

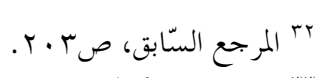

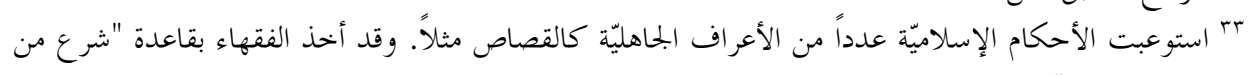


الفقه. وما تعدّد المذاهب وتعايشها، على الرّغم من اختلافاها الكثيرة، إلا دليل علـى ترى استيعاب المكوّن التّشريعي لكثرة الآراء وتنوّعها. ولهذه المرونة أصل ثابت فئ في المبــــادئ

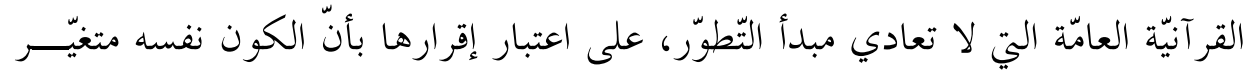

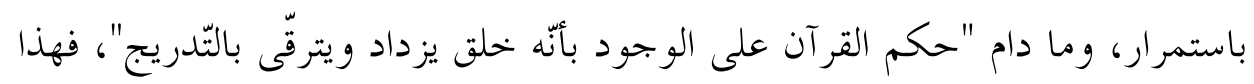

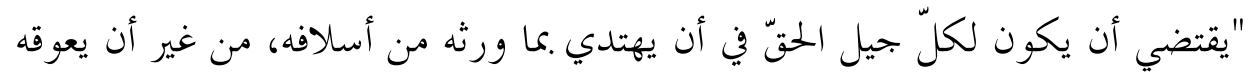

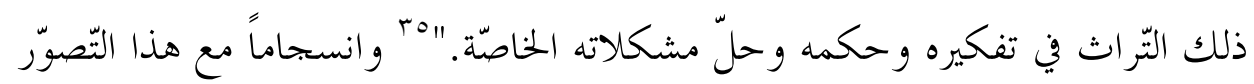

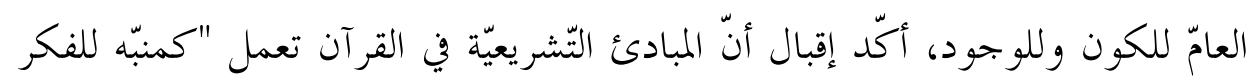

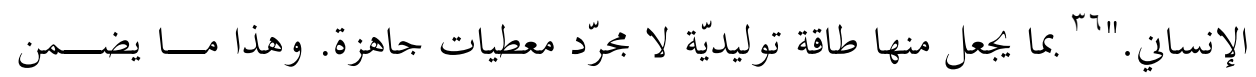

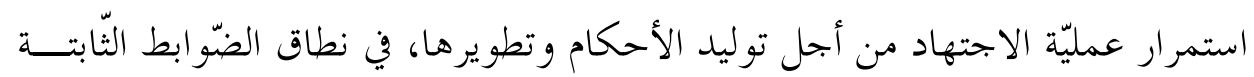
في الإسلام.

و القول بأنّ الأحكام الواردة في الأحاديث النّويّة، هي نماذج لطرائق الاجتهاد في

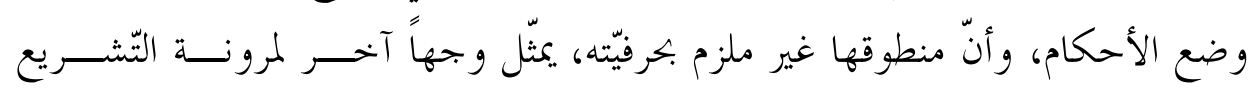

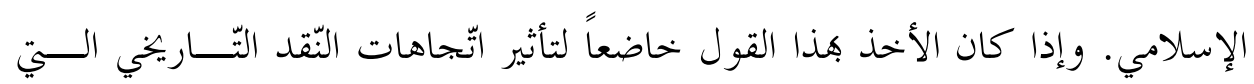

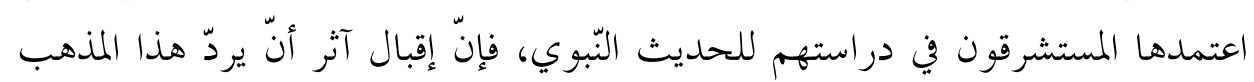
إلى أحد المجتهدين المسلمين، والمقصود بذلك شاه ولي الله الذي ألّّ على ضرورة العناية

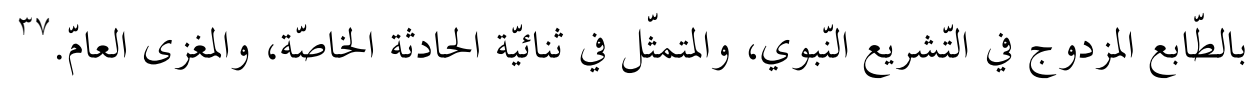

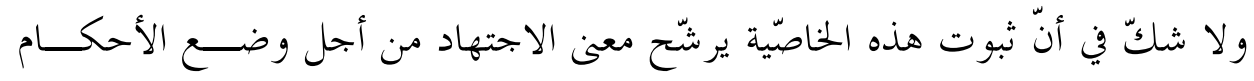
المناسبة لكل حّل حال.

ومن علامات المرونة أيضاً، القول بأنّ إجماع الصّّحابة غـــير ملــزم لمــن يـــأتي

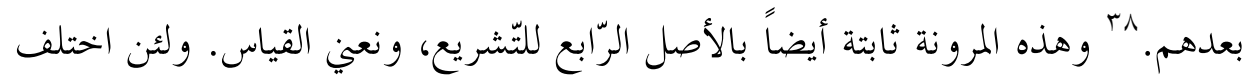

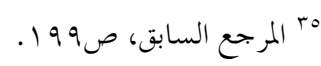

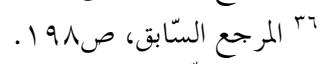

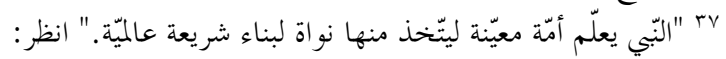

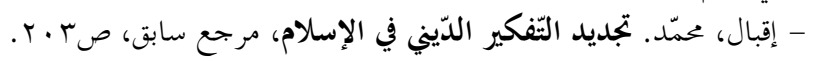

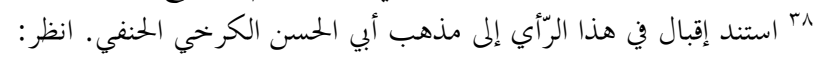




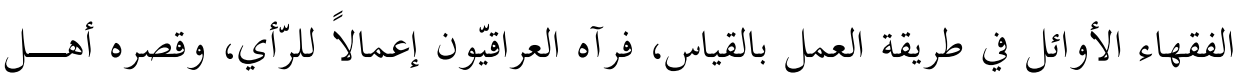

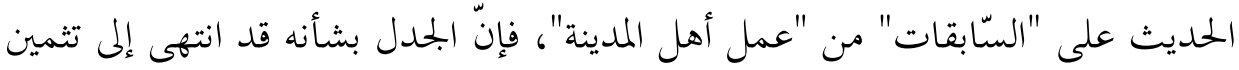

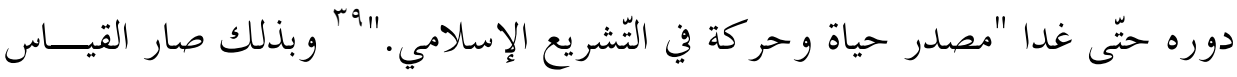

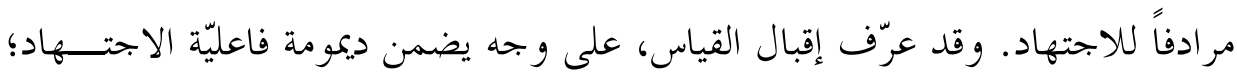

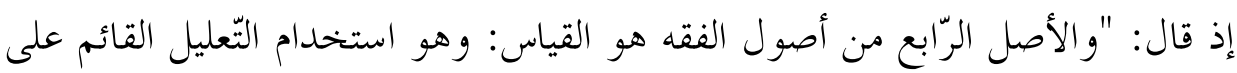

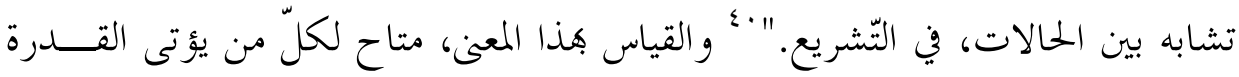
على ملاحظة "التّشابه" بين النّازلة الحاضرة، ومثيلتها الغائبة و "تعليله".

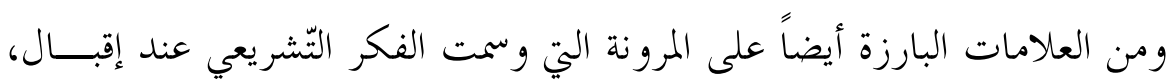

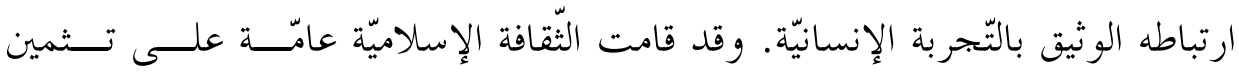

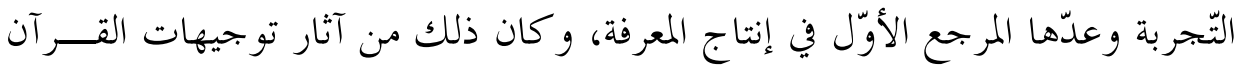

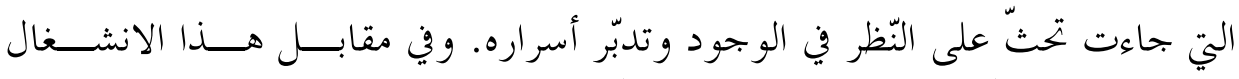

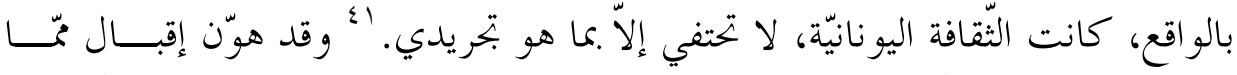

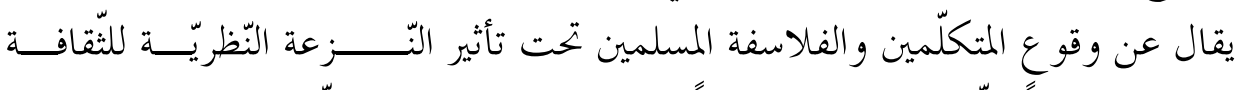

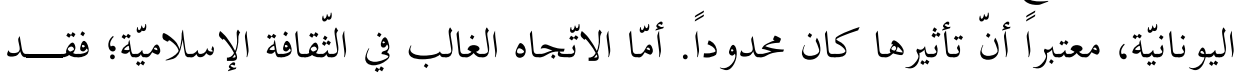

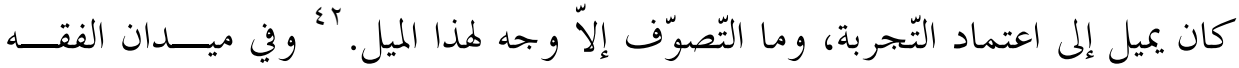

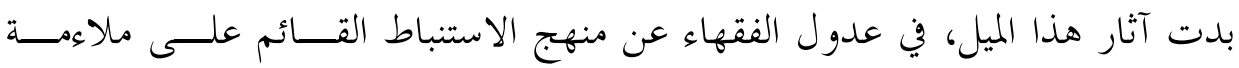

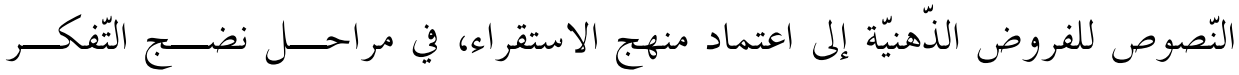

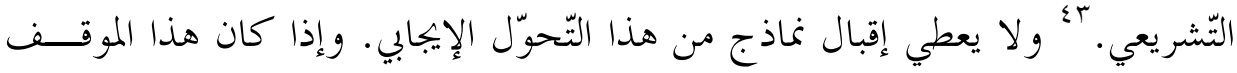

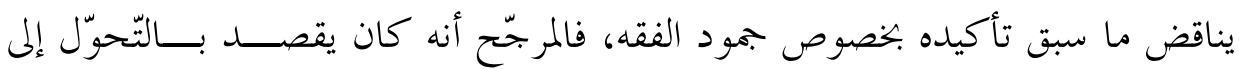

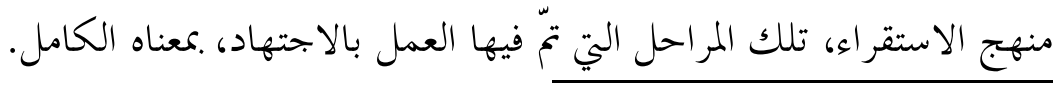

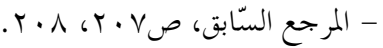

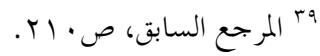

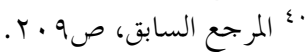

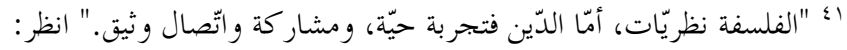

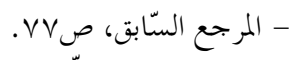

r将

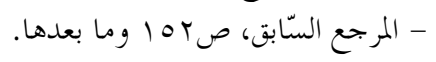

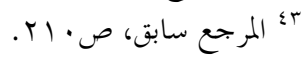


و التّجربة كامنة في أغلب الأصول حسب إقبال، فإذا كان القرآن يضع ضـــوابط

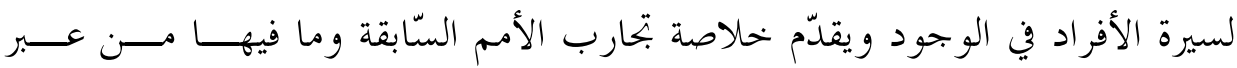

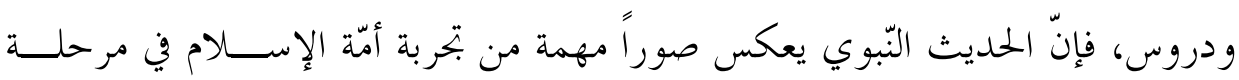

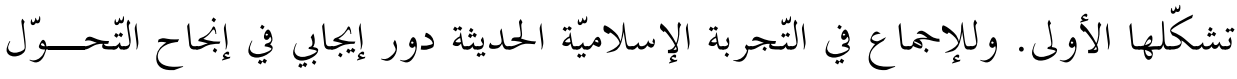

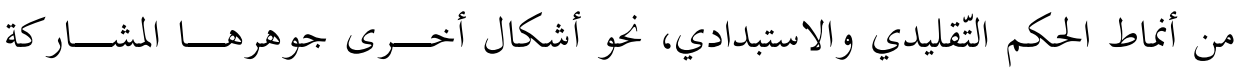

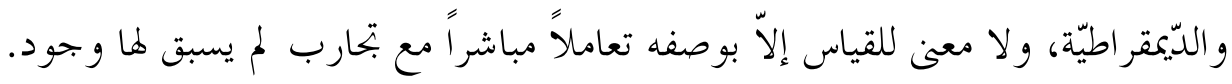
إنّ الخلاصة التي سعى إقبال إلى بلورقا، تتمثل في تأكيد قابليّة التّشريع الإسلامي للتطوّر المطرّد .مما يناسب واقع الأحوال المتبدّلة، ويكفي التّأمّل في الإمكانيّات الكامنــــة

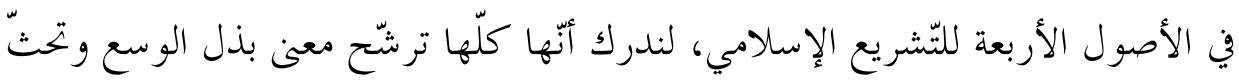
على الاجتهاد، ووي واقع المسلمين اليوم، يفتح الاجتهاد في الأصول للتّشريع الإسلامي آفاقاً رحبة، ليكون معاصراً لزمنه.

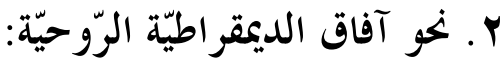

جاءت خلاصة فحص إقبال لممكنات التّجديد في الأصول الأربعة، لتؤكّد أنّها لا

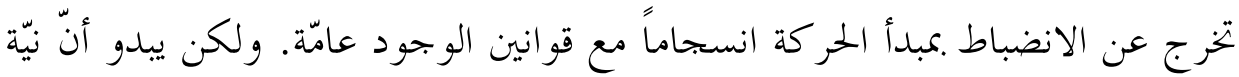

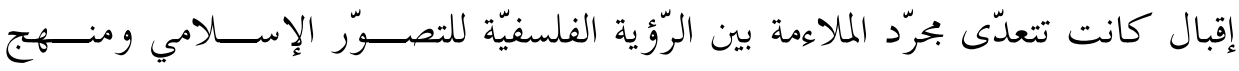
الاستنباط الفقهي؛ إذ كان يهدف إلى كشف آفاق جديدة، تتّخذ فيها مسألة الاجتهاد في التّشريع شكل هيئة دائمة، تكون بمثابة اختيار استراتيجي يؤمّن اطّر اد التّقدّم. ويبدو

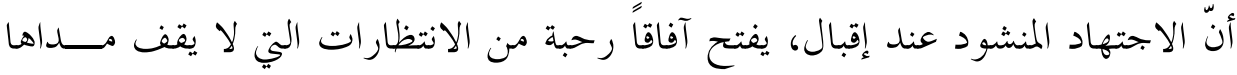
عند حدود العالم الإسلامي فحسب، بل يتجاوزها ليشمل الإنسانيّة قاطبة.

أ. الإجماع .. ذلك الأمل:

أثبت إقبال الحقّ في الاجتهاد بطريقين اثنين: طريق الأصوليين؛ إذ بيّن أنّ الأصول

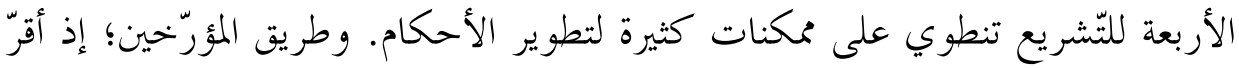




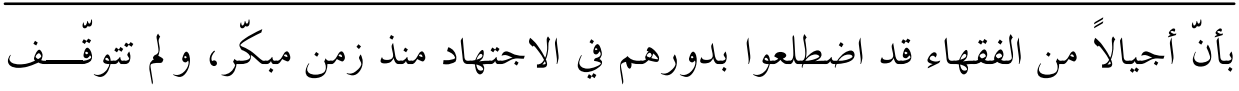

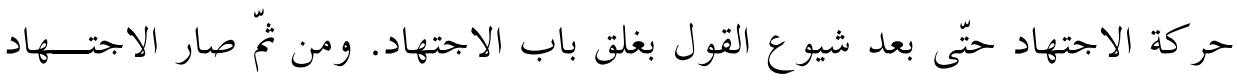

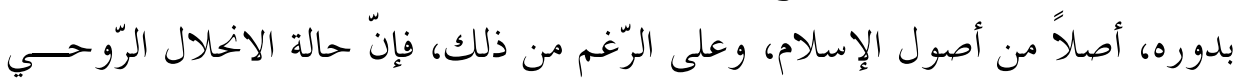

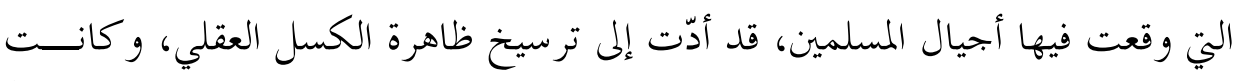

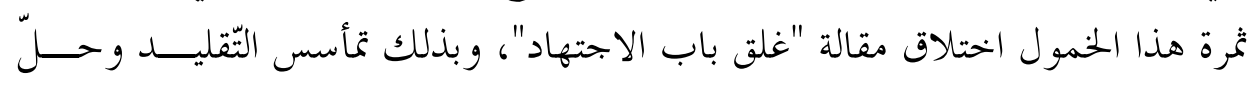
الاتبّاع محلّ التّفكير و التّدبّر . مترّ. وإذ يو اجه المسلمون في هذا العصر تحدّيات الانتقال من العالم القديم، فإنّهم بحاجة

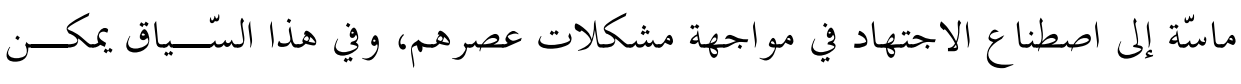
الإفادة من مرونة أصول التّشريع وقابليّها للتّلاؤم مع التّجربة الحديثة. وقد رألى رأى إقبال

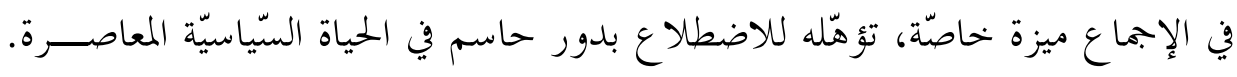

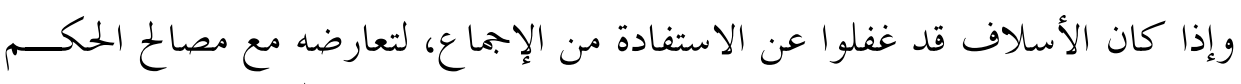

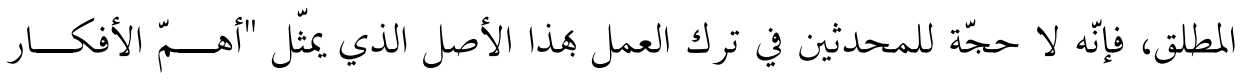

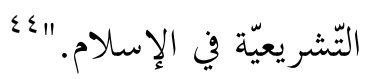

وعندما يتابع هذا المفكرّ التّحوّلات النّاشئة في أنظمة الحكم حديثاً سواء في الغرب

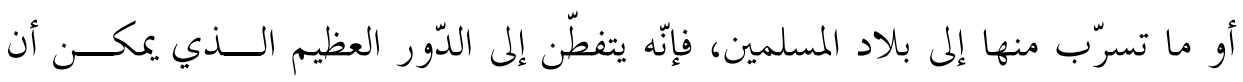

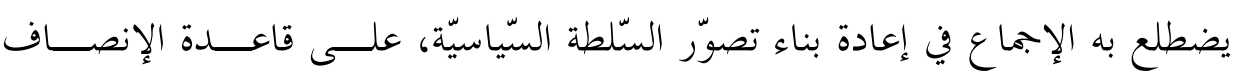

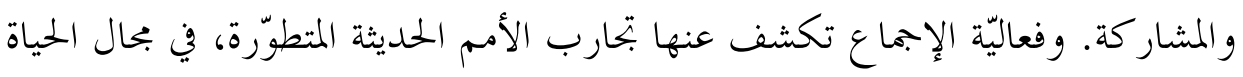

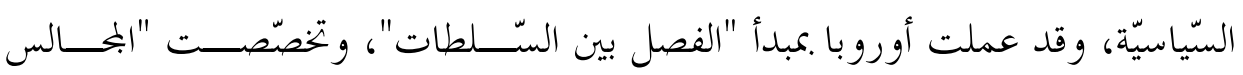

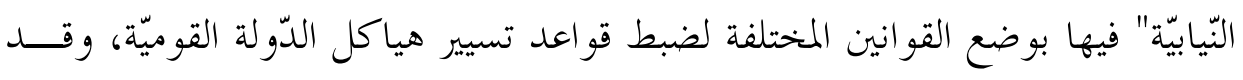

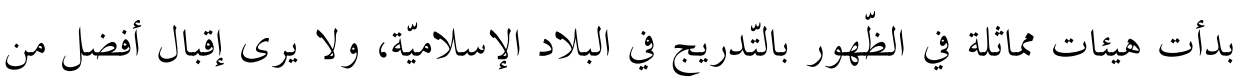

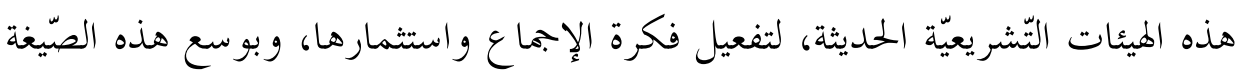

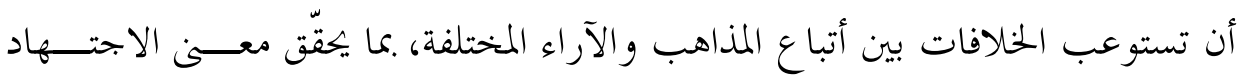

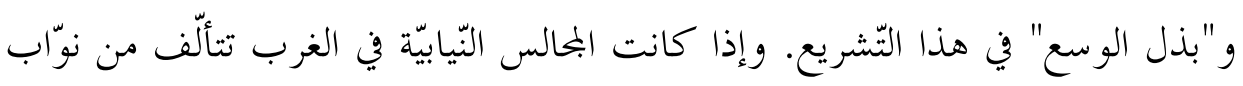


منتخبين، بصرف النّر عن مؤهلاهم العلميّة، فإنّ شرط إقبال في الانتساب إلى هـــــه الهيئة أن يكون أعضاؤها من العلماء .كسائل الدّين، إلى جانب طائفة من الخبراء "مُّـــن يكون لهم بصر نافذ في شؤون الحياة." "ه؛ وإذا اجتمع رأي الخبير برؤية الفقيه، يتقــــدم الفكر التّشريعي دون الخروج عن ضو ابطه الرّوحيّة الثّابتة.

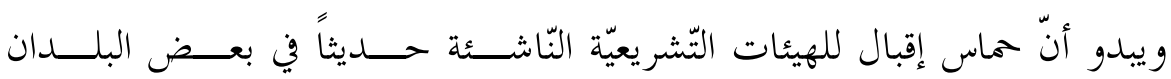

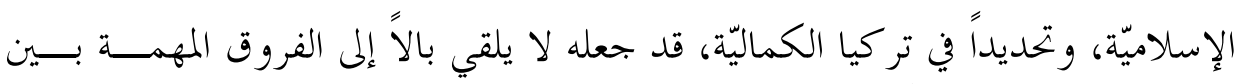

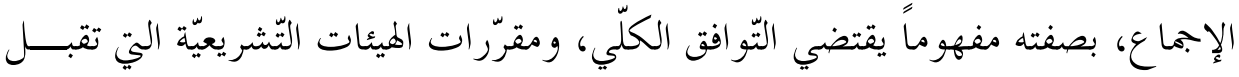

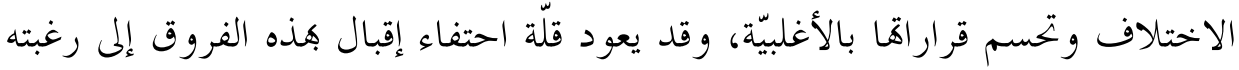

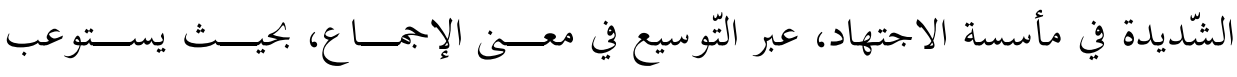

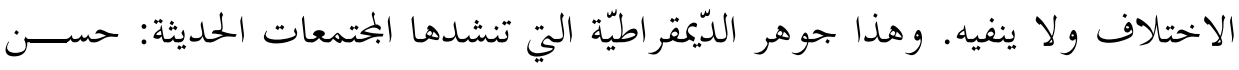

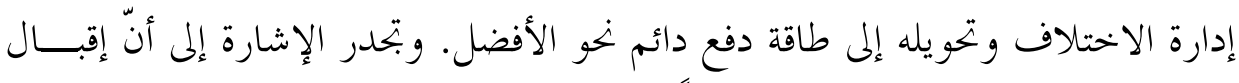

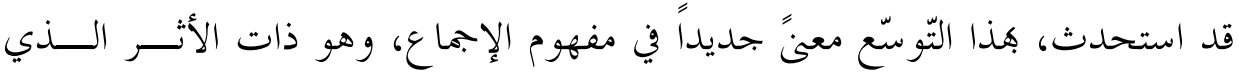

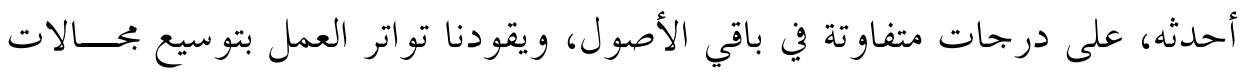

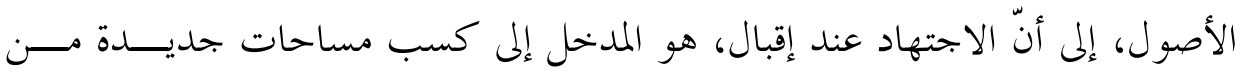
المعنى المعاصر لزمنه، وهو جوهر فعل التّجديد.

إنّ هذا التّوسّع في توليد ممكنات الأصول، لَيقيم الدّليل على عمق التّجديد الــــي

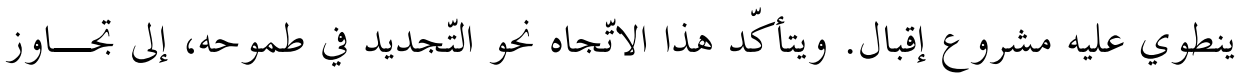

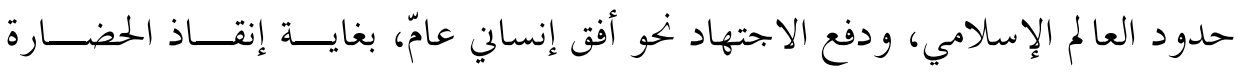
الحديثة كلّها من أدو ائها القاتلة.

\section{ب. الاجتهاد شفاء لروح الحضارة:}

علّق إقبال بلوغ الحلكم السيّاسي الصّّالح في بلاد الإسلام، علــى شــــرط تفعيـلـل

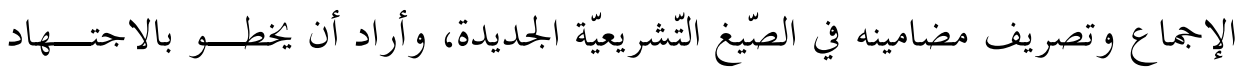

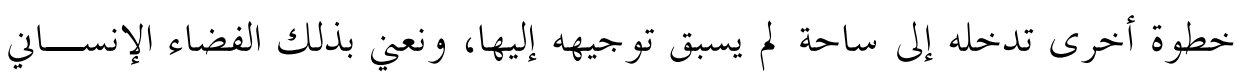




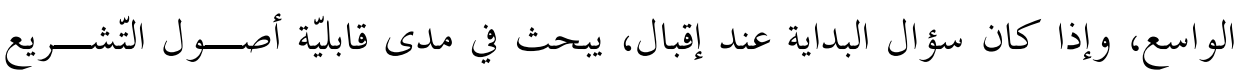

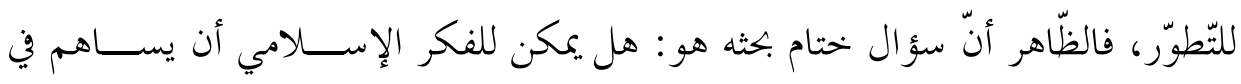

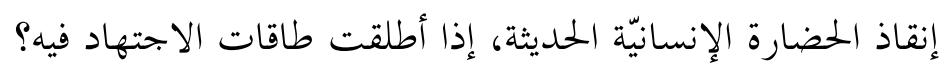

ومثل هذا السيّو ال يفترض أمرين متقابلين: الارتياب في الحضارة الحديثة، في مقابل

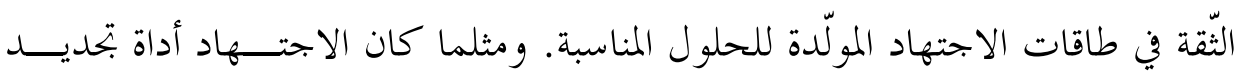

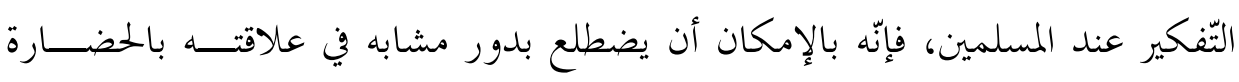

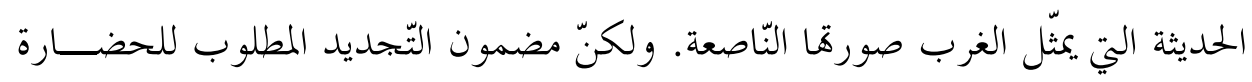

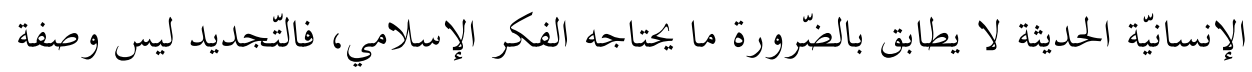

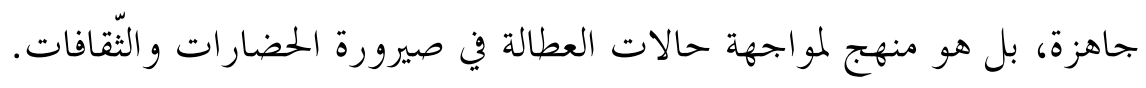
نادى إقبال بتفعيل مبدأ الحركة كة، لبعث الحياة في الفكر الإسلامي الــذي أصـابه

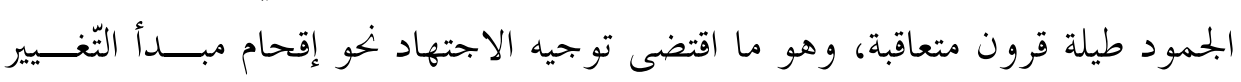

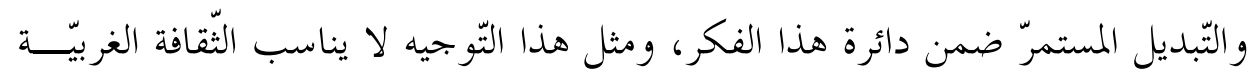

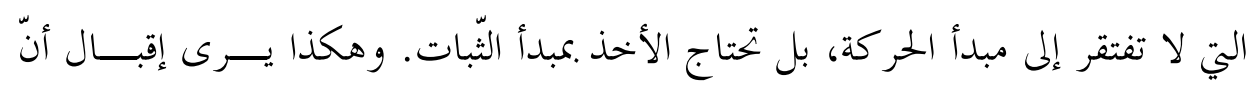

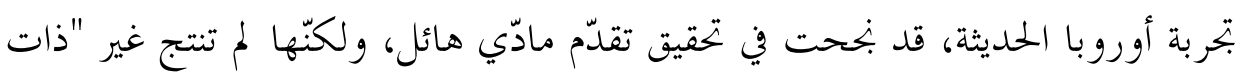

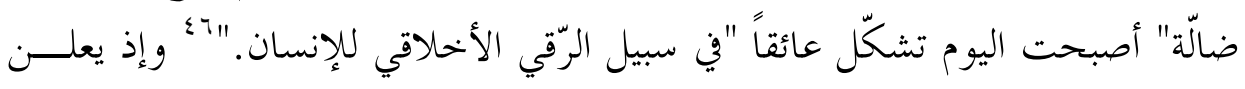

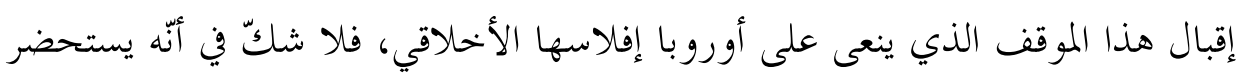

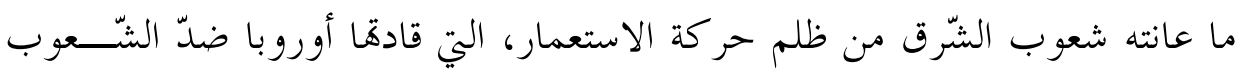

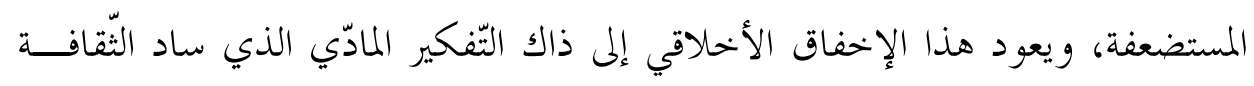

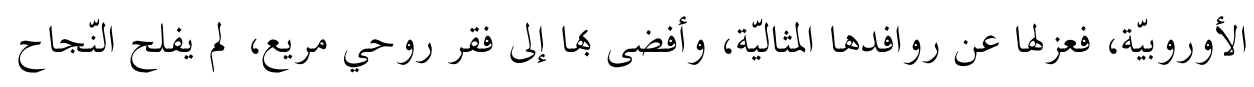
التّقي الباهر في معالجته.

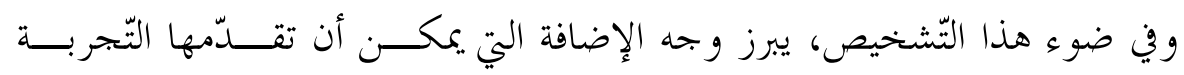

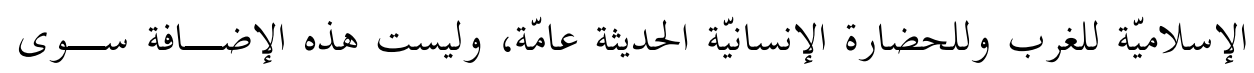

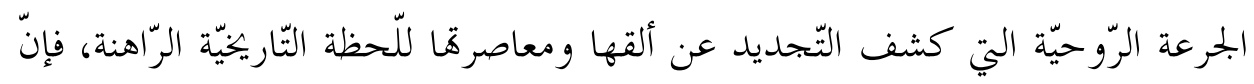

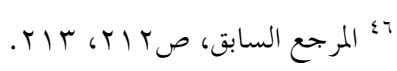




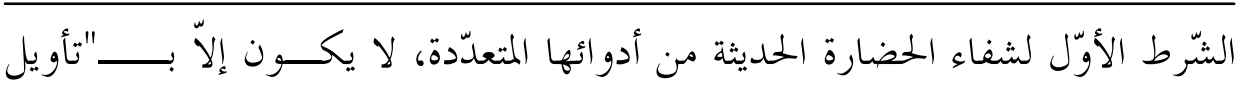

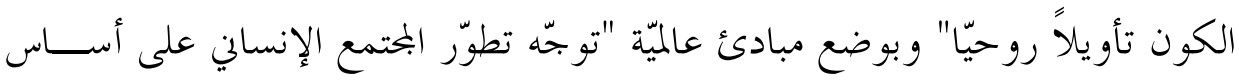

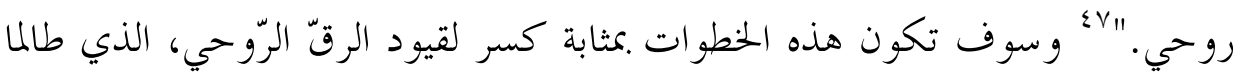

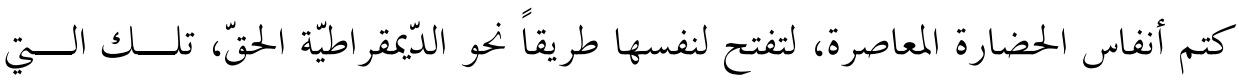

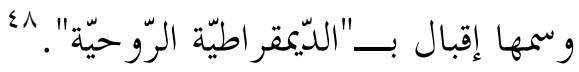

والخلاصة التي انتهي إليها إقبال، لا تخرج عن ضو ابط مبتدأ بحثه، ونعين محاولـــة

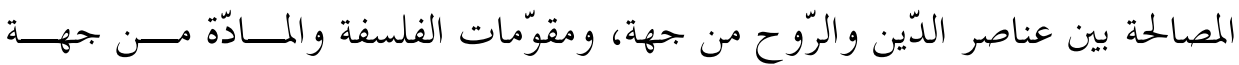

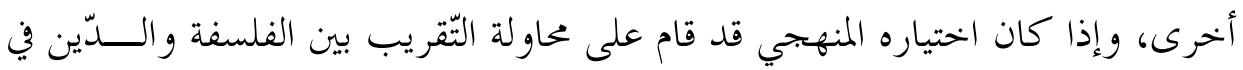

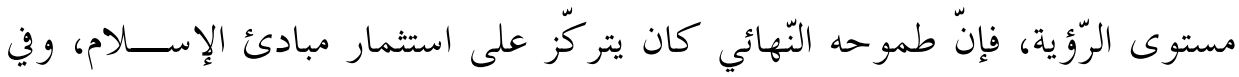

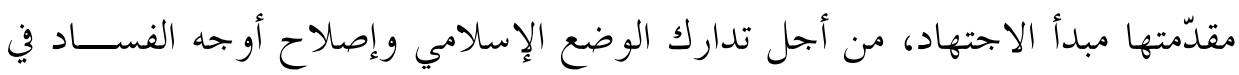

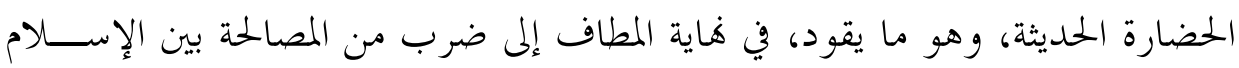

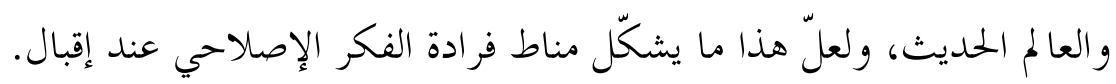

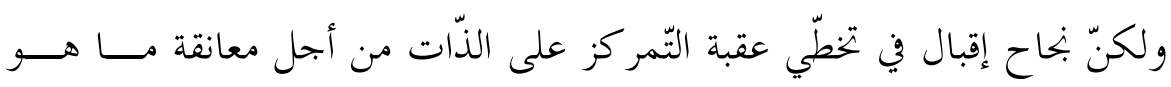

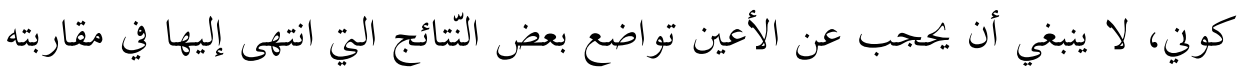

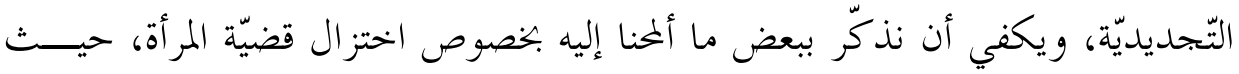

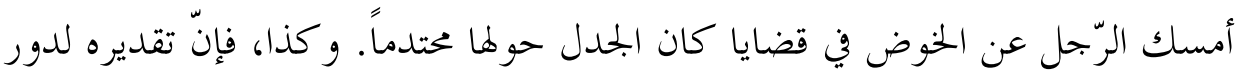

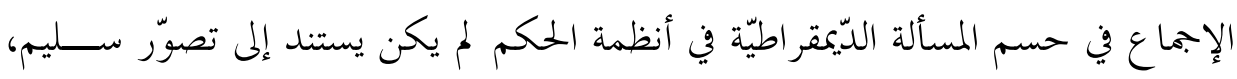

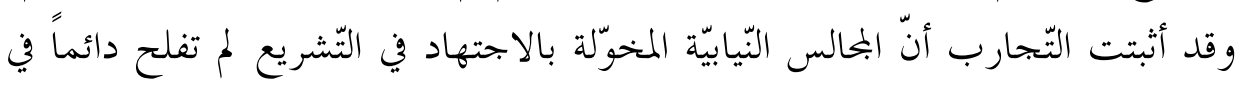

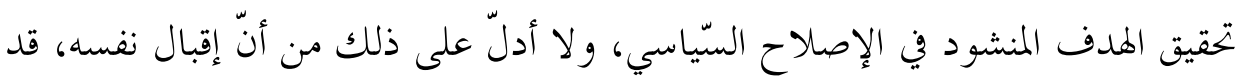

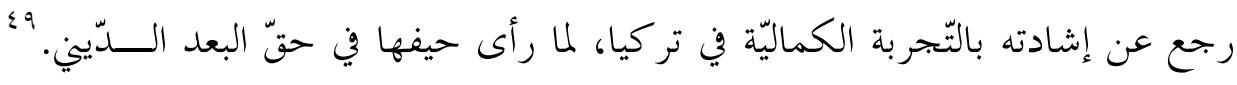

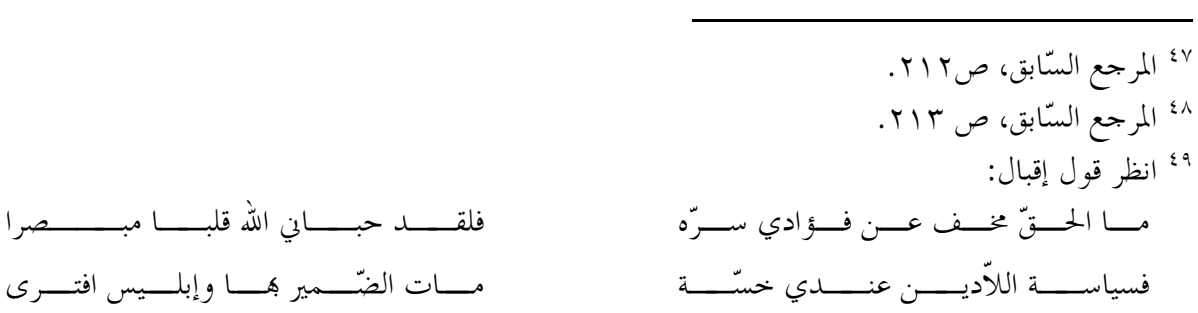

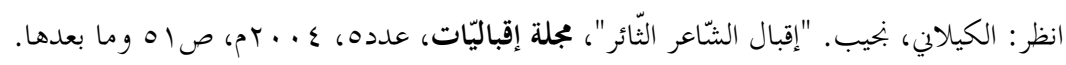


و لا تسلم مقترحات إقبال المتّصلة بتجديد الأصول التّشريعيّة من المآحذ؛ إذ اكتفى فيها

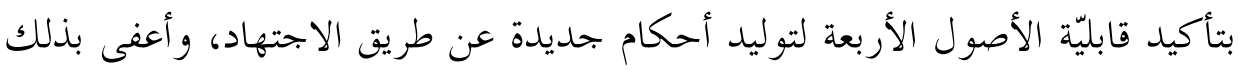

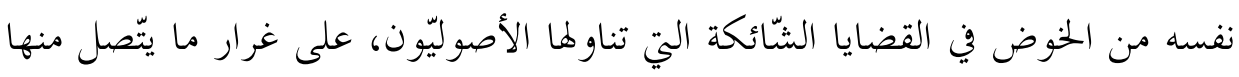

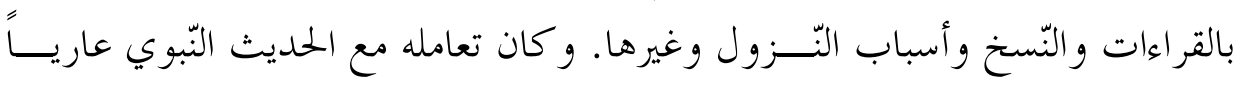

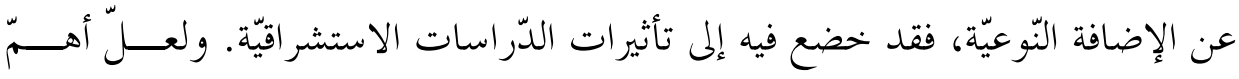

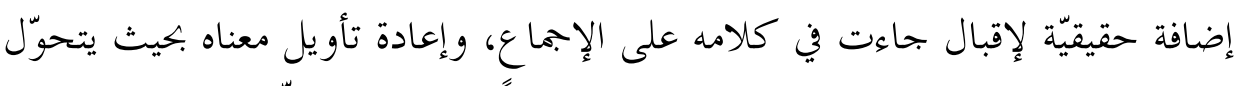

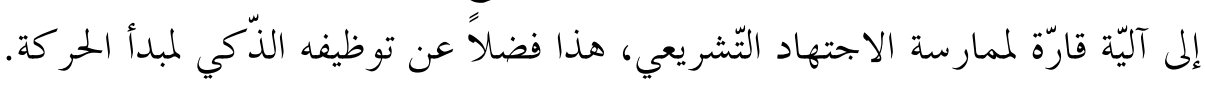

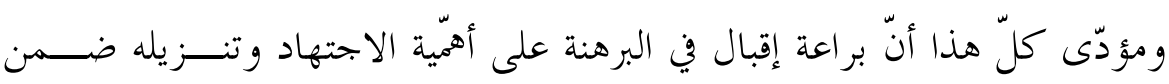

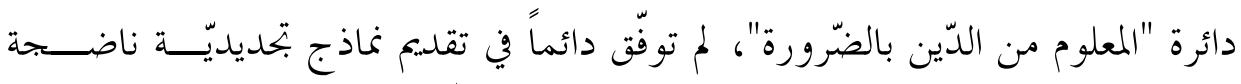

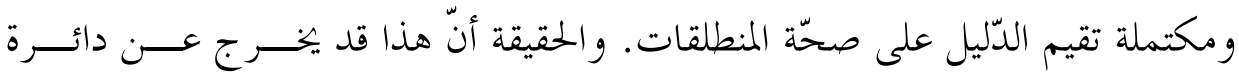

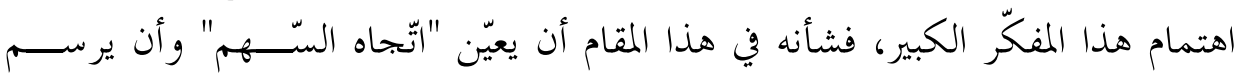

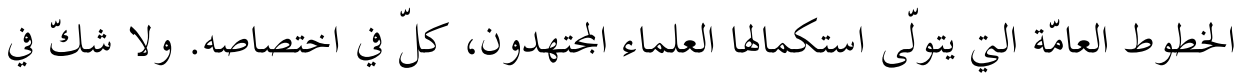

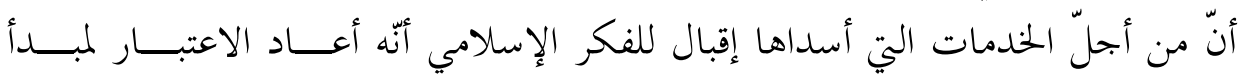

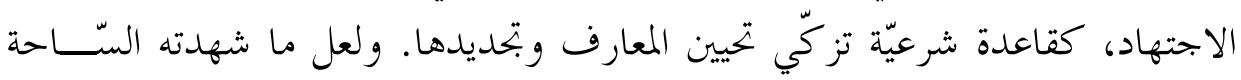

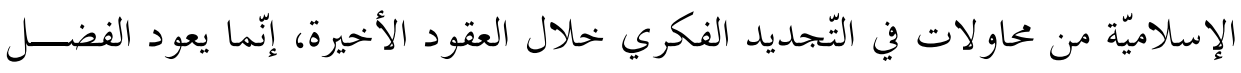
فيها إلى الجهر الصّادق الذي بذله إقبال وأمثاله من المحدّدين.

خاتمة:

في مغامرة التّجديد، اختار إقبال تأليف رؤية شاملة لبلورة ملامح أفــق إســلامي

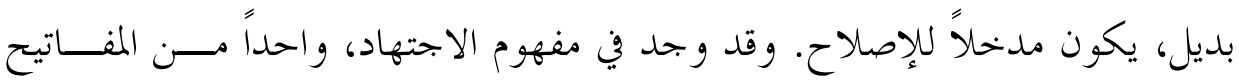

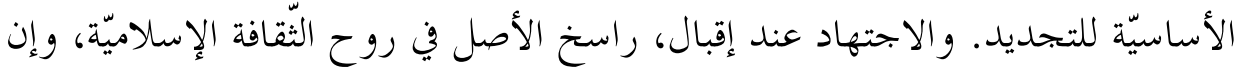

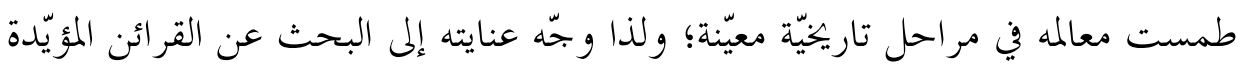

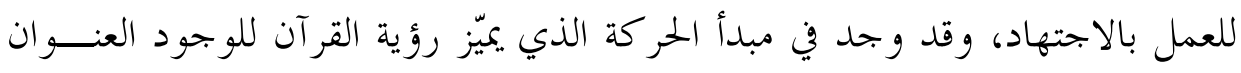
الأبرز على انحياز الثّقافة الإسلاميّة إلى فكرة التّجديد مبديد. 
و كان مدار الاجتهاد عند إقبال على الاجتهاد ذاته: وهو ما يعني إطلاق فعاليّتــهـ

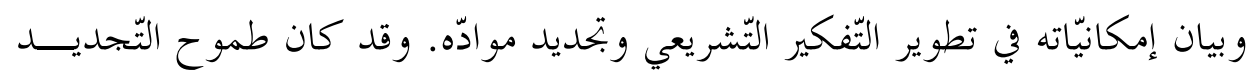

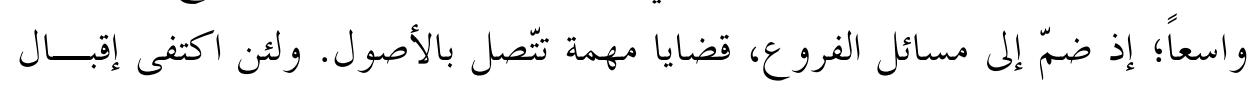

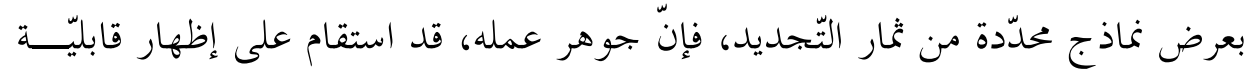
الفكر التّشريعي الإسلامي للتّطوّر ومواكبة النّوازل المتبدّلة. و لم يكن بناح الاجتهاد في تطوير التّشريعات في الثّقافة الإسلاميّة مطلوباً لذاتــه؛

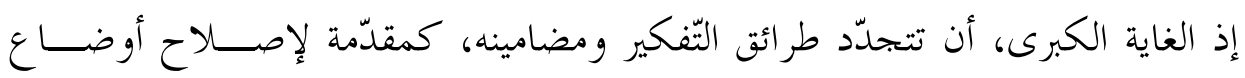

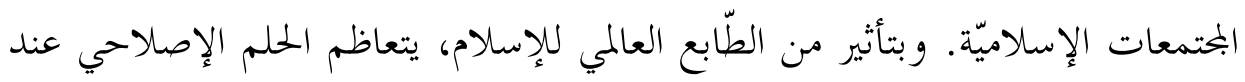

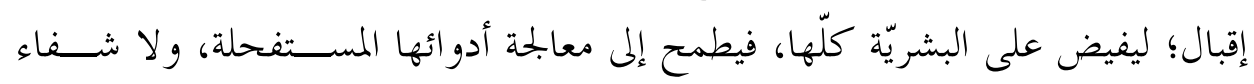

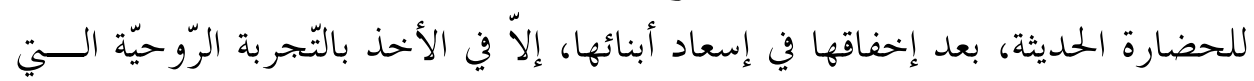

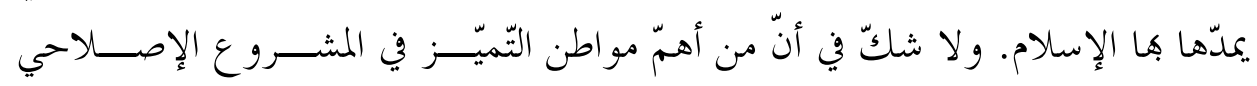

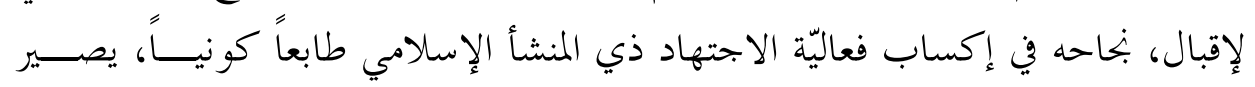

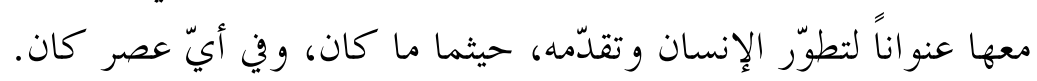

وإنّ من أسرار بلاغة الدّعوة الإصلاحيّة لدى إقبال أنّ اتّجاه السّهم فيها يشير إلى

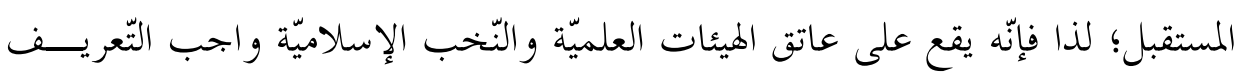

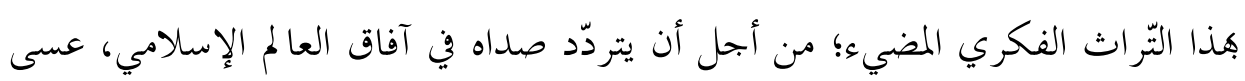

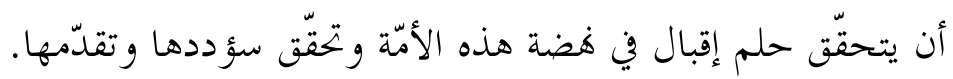

